\title{
路盤振動がバラスト層の塑性沈下挙動に 及ぼす影響に関する研究
}

\author{
千田 耕大 1 松島 亘志 2 三輪 昌弘 $3 \cdot$ 川崎 祐征 4 \\ 1正会員 東海旅客鉄道株式会社 総合技術本部技術開発部（†485-0801 愛知県小牧市大山1545-33） \\ E-mail: koudai.senda@jr-central.co.jp \\ 2 正会員 筑波大学教授 システム情報系構造エネルギー工学域（テ305-8573 茨城県つくば市天王台 1-1-1） \\ E-mail: tmatsu@kz.tsukuba.ac.jp \\ 3正会員 東海旅客鉄道株式会社 総合技術本部技術開発部（一485-0801 愛知県小牧市大山1545-33） \\ E-mail:m.miwa@jr-central.co.jp \\ 4正会員 東海旅客鉄道株式会社 総合技術本部技術開発部（一485-0801 愛知県小牧市大山1545-33） \\ E-mail: yoshiyuki.kawasaki@jr-central.co.jp
}

\begin{abstract}
バラスト軌道において軌道狂いの進行を抑制することは，列車の快適な乗り心地を維持するうえで重要 な課題である．列車走行時に生じる路盤振動は，この軌道狂いの進行に大きな影響を与えている要因のひ とつと考えられる，そこで本研究では，実物大軌道における繰返し載荷試験および個別要素法を用いたシ ミュレーションモデルにより路盤振動がバラスト軌道の沈下に与える影響について考察した. 研究の結果, 路盤剛性が小さく，路盤振動が大きくなるとバラスト軌道の沈下量が大きくなることを定量的に示し，路 盤振動の加速度が重力加速度を上回ると軌道沈下量が急激に大きくなること, 軌道沈下量が路盤の振動速 度と相関が高いことを明らかにした。
\end{abstract}

Key Words : roadbed stiffness, loading frequency, ballasted track, sleeper settlement, acceleration of roadbed, velocity of roadbed

\section{1. 緒言}

鉄道において最も基本的な軌道構造であるバラスト軌 道は，国内外の多くの鉄道で採用されている，バラスト 軌道は，一定割合で発生する軌道狂いに対する保守を前 提とした軌道であるため, 良好な乗り心地を維持するに は，マルチプルタイタンパーなどの大型機械を用いて定 期的に軌道狂いの整正作業が必要である。しかし，一部 の区間では周囲に比べて特に上下方向の軌道狂い（以下， 本論文ではこの上下方向の軌道狂いを「軌道狂い」とい う）の進行が速く, 狂い量が一定值に達した都度, 局所 的に人力での非効率な保守を必要としている. 軌道狂い の進行が速い要因には，構造物境界などによる軌道支持 剛性の急変や，レール継目，溶接などの構造的不連続に よる輪重変動の増加などが挙げられる. しかし，一部に はこのような明確な要因が見つからない場合もある。こ のように要因が不明確な箇所での軌道狂い進みは，発生 場所や時期を予測することが難しい場合があり，保守現 場では対応に苦慮している，また，要因が不明確である
ため抜本的な対策を講じることも難しい.

バラスト軌道において軌道狂いの進行が速くなる要因 のひとつが路盤にあることは, 経験的にもこれまでの研 究からも言及されているが 12)，そのメカニズムは明確 にされていない．路盤の挙動がどのようなメカニズムで 軌道狂いの進行に影響しているかを明確にし，特に急激 な沈下が発生するとき，どのようなパラメータが支配的 要因となるのかを明らかにすることはバラスト軌道の建 設・維持管理の上で重要な課題である.

また, 高速鉄道では, 列車通過に伴ってバラスト軌道 が加振される周波数が在来線に比べて高いという特徽が ある，例えば東海道新幹線では，主に軸距間隔に起因し て生じる荷重の周波数は $30 \mathrm{~Hz}$ 以上に相当する.このよ うな比較的高い周波数の振動が軌道狂いに与える影響に ついても解明する必要がある.

車両走行時に発生する軌道振動に関しては, 佐藤 3や 三浦 ${ }^{4}$ が解析モデルを構築しており，これらをべースと した検討も行われている5.（しかし，これらのモデルで は実際の沈下挙動を再現することはできない。また，バ 


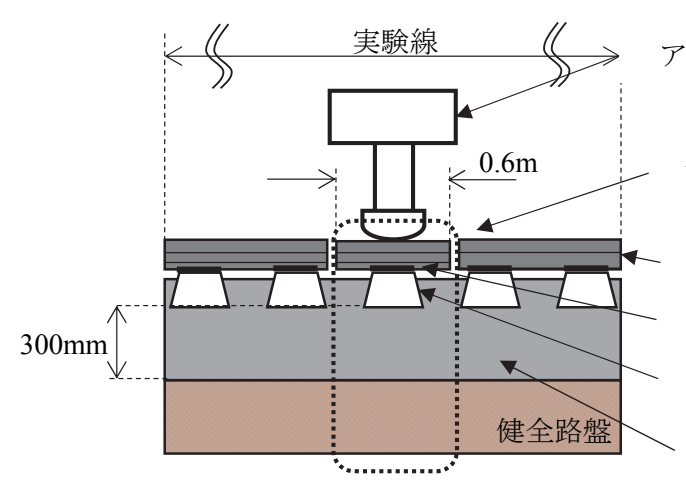

(a) 健全路盤

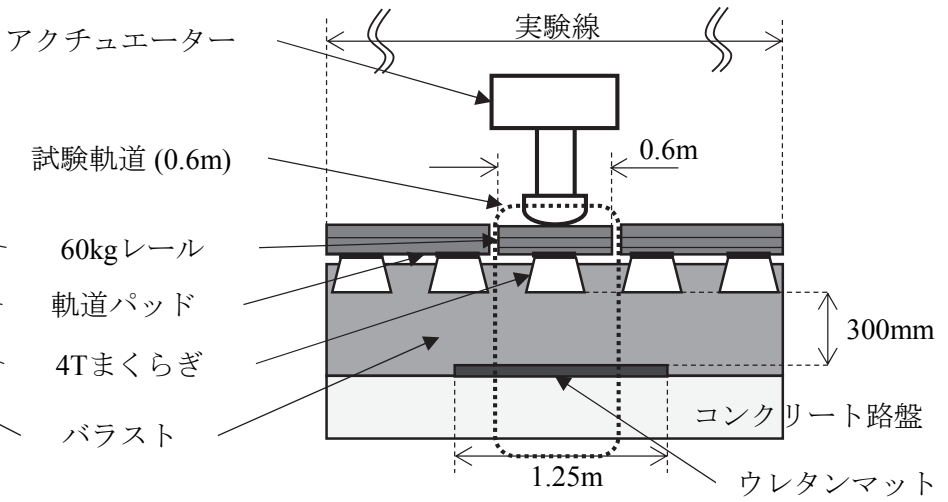

(b) 模擬軟弱路盤

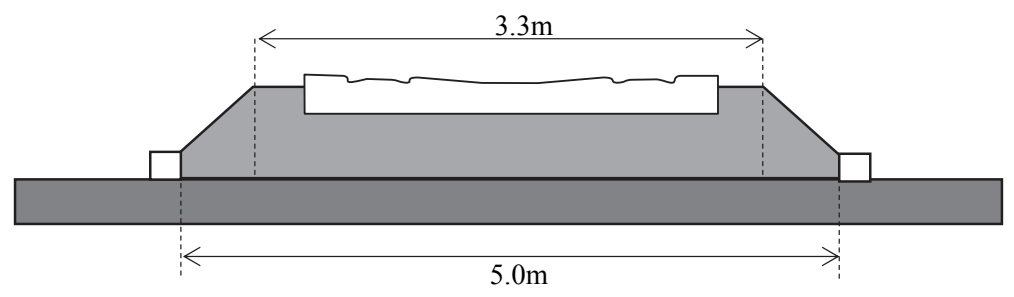

(c) レール直角方向断面（健全路盤・模擬軟弱路盤共通）

図-1 試験軌道

ラスト軌道の沈下挙動に関する実験的研究についてもこ れまでに多く行われているが1，2，の》，30Hzを超えるよ うな比較的高い周波数域を考慮して載荷周波数と軌道沈 下量との関係を検証している例はあまり多くない，そこ で，本研究では高速鉄道を想定し，軌道沈下現象を試験 および解析で再演し，軌道狂いの急激な進行メカニズム の解明に取り組む.

筆者らは，東海道新幹線のバラスト軌道各部の振動測 定を実施し，軌道狂いの進行有無とバラスト・路盤の振 動との関係について調査・分析を行ってきた8). また, 実物大軌道を用いた繰返し載荷試験および2次元個別要 素法（以下，DEMという）を用いたシミュレーション により，路盤振動が大きい条件で軌道沈下量が大きくな ることなどを確認した9). 本研究では, これらの結果を もとに，DEMを用いてより詳細な解析を行い，列車か ら入力される繰返し荷重の大きさや周波数が軌道沈下に 与える影響や，路盤振動が軌道沈下を発生させるメカニ ズムについて論ずる.

\section{2. 実物大バラスト軌道による繰返し載荷試験 ${ }^{9}$}

実物大軌道を用いて繰返し載荷試験を実施し, 路盤岡 性と軌道各部の応答, 軌道沈下量との関係について解明 する. 本章の内容は主に文献 9ですでに公表したもので あるが，追加部分があるとともに，解析結果との比較に
おいて必要な内容であるため，一部簡略化して述べるこ ととする.

\section{(1) 試験概要}

\section{a) 実物大バラスト試験軌道}

本試験は実物大試験用軌道の中に試験軌道を作製して 実施する，試験軌道を図-1に示寸，試験軌道はレールを 長さ 0.6 mに切断することで，まくらぎ1本分の延長とす る.レールを切断するのは, 繰返し載荷により載荷点が 浮きまくらぎとなるのを防止するためである、レールお よびまくらぎは東海道新幹線で一般的に用いられている 60kgレールとPCまくらぎ（4T型10)）とする. バラストも 東海道新幹線で使用しているものと同様であり, 定めら れた粒度分布の基準11を満たすものである. バラスト厚 さはまくらぎ下 $300 \mathrm{~mm}$ とし, 軌道パッドはレール圧力 測定用の厚さ $10 \mathrm{~mm}$ タイプのものを使用する. 路盤条件 は，有道床軌道の設計基準12)分に満たす健全な土路 盤（以下，健全路盤という）および既往の研究等を参考 に ${ }^{13)}$ ，コンクリート路盤上にばね定数の小さいウレタン 製のマットを敷いた模擬軟弱路盤（以下，模擬軟弱路盤 という）の2種類を設定する. 試験軌道の主な条件を表1に示寸．なお，表-1中の地盤反力係数K301設定した路 盤上で小型FWD装置14)用いて測定したものである.

\section{b) 移動式載荷試験車}

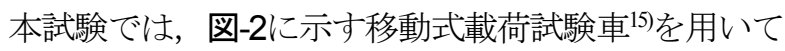
載荷を行う。本試験装置は載荷台車と起振台車の $2 つ の$ 
表-1 試験軌道条件

\begin{tabular}{lr}
\hline \multicolumn{1}{c}{ 項目 } & \multicolumn{1}{c}{ 仕様 } \\
\hline レール & $60 \mathrm{~kg}$ レール \\
軌道パッド & $110 \mathrm{MN} / \mathrm{m}$, 厚さ $10 \mathrm{~mm}$ \\
(レール圧力測定用 $)$ & $4 \mathrm{~T}$ \\
まくらぎ & 300 \\
バラスト厚さ $(\mathrm{mm})$ & 199 \\
地盤反力係数 健全 & 20 \\
$K_{30}\left(\mathrm{MN} / \mathrm{m}^{3}\right) \quad$ 模擬軟弱 & $1250 \times 4250 \times 30$ \\
マット寸法 $(\mathrm{mm})$ & 0.030 \\
マット剛性(公称值 $)\left(\mathrm{N} / \mathrm{mm}^{3}\right)$ & \\
\hline
\end{tabular}

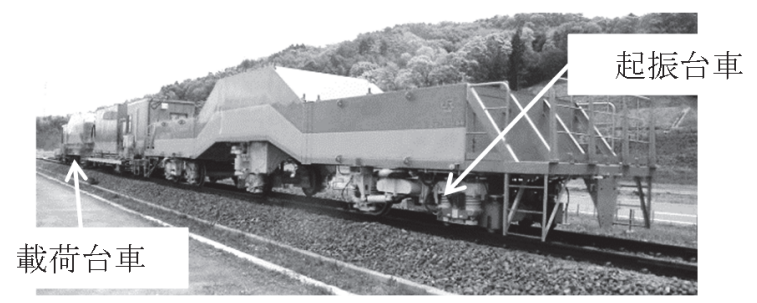

(a) 全体図

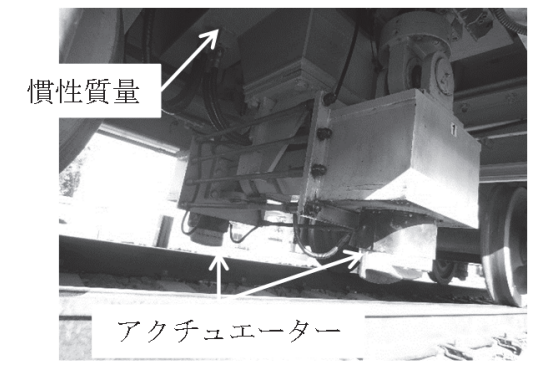

(b) 載荷台車

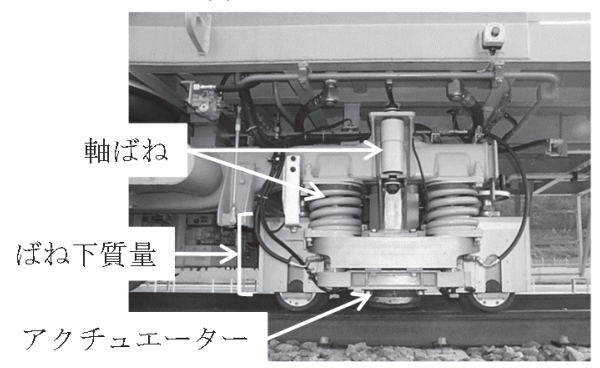

(c) 起振台車

図-2 移動式載荷試験車

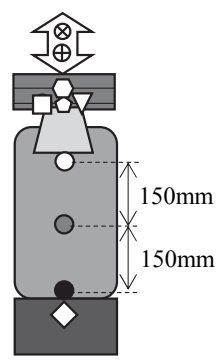

$\otimes$ 載荷変位

$\oplus$ 載荷荷重

○レール加速度

○まくらぎ加速度

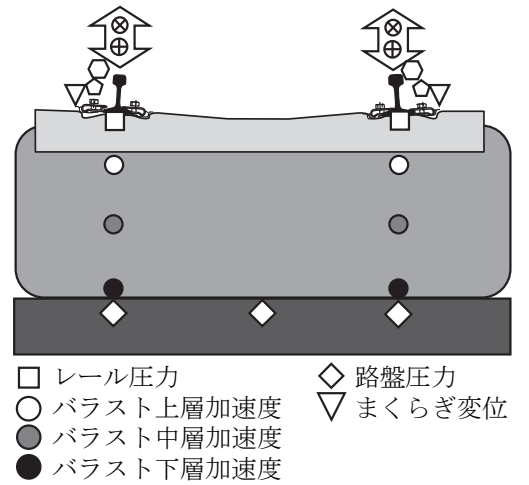

図-3 測定項目
載荷装置で構成される，載荷台車は最大輪重 $120 \mathrm{kN}$ ，最 高周波数 $40 \mathrm{~Hz}$ での繰返し載荷が可能な載荷装置である. 起振台車は, 新幹線車両とほぼ同一の質量・ばね特性の もとで軌道を加振できる載荷装置で, 加振時の最高周波 数は $150 \mathrm{~Hz}$ である.

\section{c) 試験方法および測定項目}

本試験では，2 種類の載荷試験を実施する。ひとつは 載荷台車を用いた繰返し載荷試験（以下，繰返し載荷試 験という），もうひとつは起振台車を用いた振動特性試 験である（以下，振動特性試験という）。

繰返し載荷試験では，各路盤条件・載荷周波数による 軌道沈下量の違いを検証するため，荷重制御による正弦 波載荷を行う。荷重条件は軌道片側あたり $30 \pm 20 \mathrm{kN}$ と 寸る．振幅中心である $30 \mathrm{kN}$ は軌きょう剛性による荷重 分散効果を考慮したとき10の輪重に相当する．また，振 幅值は列車走行時の輪重変動および試験装置の動作安定 性を考慮して設定した，載荷時はまず $30 \mathrm{kN}$ をべース荷 重として与えたのち，正弦波荷重を入力する．ベース荷 重は加振時に試験装置を安定的に動作させるために与え ている．試験では，バラスト層の初期沈下を完了させる ため, $30 \mathrm{~Hz}$ で 50,000 回の載荷を実施した後, $5 \mathrm{~Hz}$ から $40 \mathrm{~Hz}$ まで $5 \mathrm{~Hz}$ 刻みで周波数を変化させながら各 40,000 回の載荷を行う。

振動特性試験は，繰返し載荷試験終了後，そのままの 軌道状態で引き続き実施する，本試験は，各路盤条件に おける軌道の振動特性を検証するため, 起振台車にラン ダム波の強制変位を入力する.このランダム波は変位の スペクトルが式(1)に示す分布となるように設定された 40 秒間の波で $150 \mathrm{~Hz}$ までの周波数成分を含む.

$$
a(f)=\frac{30}{f}
$$

ここで, $a(f)$ : 変位振幅 $(\mathrm{mm}), f:$ 周波数 $(\mathrm{Hz})$ である. 本試験における測定項目を図-3に示寸.

\section{(2) 試験結果および考察}

\section{a) 繰返し載荷試験}

繰返し載荷試験から得られた2種類の路盤条件におけ るまくらぎ沈下曲線を図-4に示寸，このまくらぎ沈下量 は, 各載荷回数到達時に一旦載荷を停止し, ベース荷重 が作用した状態で, 試験軌道外方の不動点から測定した 沈下量である. また, 左右のまくらぎ沈下量の平均值で 表している. いずれの路盤条件でも, 試験開始直後から 比較的急激な初期沈下が生じており，概ね20,000 回まで に収束している，その後は，緩やかな沈下が発生してお り，これらの傾向は既往の研究のとも同様である. その 後, 周波数を変えながら載荷していくと, 一定の周波数 以上で沈下量が大きくなっているが，沈下量が大きくな 


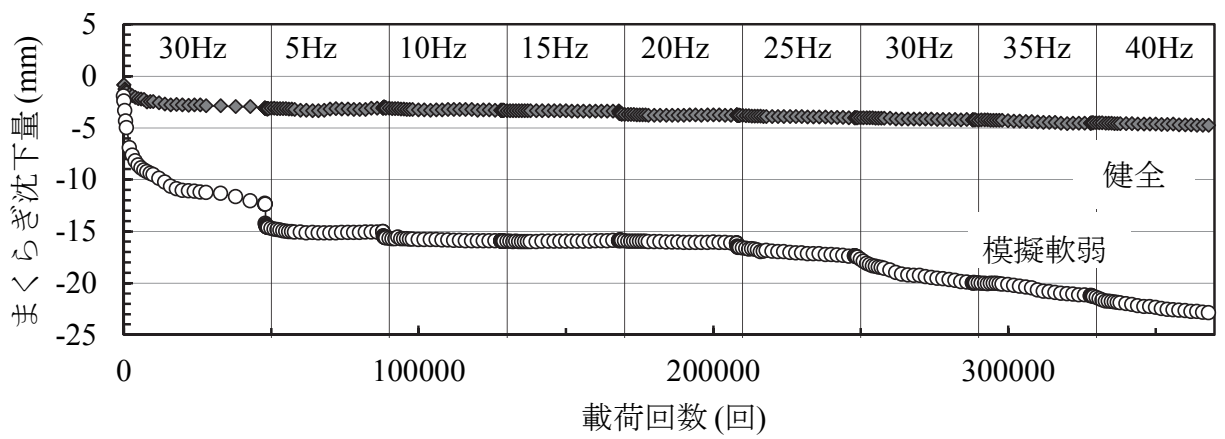

図-4 まくらぎ沈下曲線

った周波数での載荷開始直後では，初期沈下時と同様の 比較的急な沈下が生じている，模擬軟弱路盤を例に取る と, 初期載荷後, $5 \mathrm{~Hz} \sim 20 \mathrm{~Hz}$ までは周波数を変化させて も初期沈下は生じておらず，緩やかな沈下もごく小さい. 一方， $25 \mathrm{~Hz}$ 以上では周波数を変更した直後から一時的 に沈下が急激になり，その後は緩やかになるものの，25 $\mathrm{Hz}$ 未満のときに比べて沈下量は大きくなっている．健 全路盤ではこのような傾向はほとんど見られない.

各周波数で加振した際に発生したまくらぎ沈下量を図 -5に示す. まくらぎ沈下量は, 各周波数における初期沈 下の影響を除くため，40,000 回の載荷のうち，後半 20,000 回の載荷で発生した沈下量を示している．健全路 盤におけるまくらぎ沈下量は, $25 \mathrm{~Hz}$ でやや大きいもの の30 Hz以下では全体的に小さく，35 Hz，40 Hzで微増し ている．模擬軟弱路盤におけるまくらぎ沈下量は，20 Hz以下では小さいが， $25 \mathrm{~Hz}$ 以上で急激に増加して $35 \mathrm{~Hz}$ で最大となり， $40 \mathrm{~Hz} ゙$ は減少傾向となっている．各路 盤条件におけるまくらぎ沈下量の最大值は，健全路盤が $0.19 \mathrm{~mm}$ ，模擬軟弱路盤が $0.76 \mathrm{~mm}$ であり，模擬軟弱路盤 におけるまくらぎ沈下量は健全路盤の4倍となっている. 試験結果から，同一の荷重条件で繰返し載荷を行うと路 盤岡性が小さいほうが総じてまくらぎ沈下量は大きくな ることがわかる．また，まくらぎ沈下量は載荷周波数と 単純な比例関係とはならず，ある周波数で極大值を有す ることがわかる。

載荷周波数と軌道各部の鉛直下向き最大加速度の関係 を図-6に示す．また，40Hz載荷時の各部の加速度波形を 図-7に示寸．加速度波形は載荷初期からほとんど変化が なく安定しているため, 代表して載荷5,000 回目付近の データを用いる，図-6を見ると，いずれの路盤条件でも 軌道各部の応答加速度は載荷周波数が高くなるにしたが って増加傾向を示している，健全路盤では，レールとま くらぎ間，まくらぎとバラスト上層間，バラスト内の各 層間でそれぞれ加速度が減衰されており，40 Hzではバ ラスト下層の加速度はレール加速度の50\%程度となって いる. 一方, 模擬軟弱路盤ではこれらの減衰は小さく,

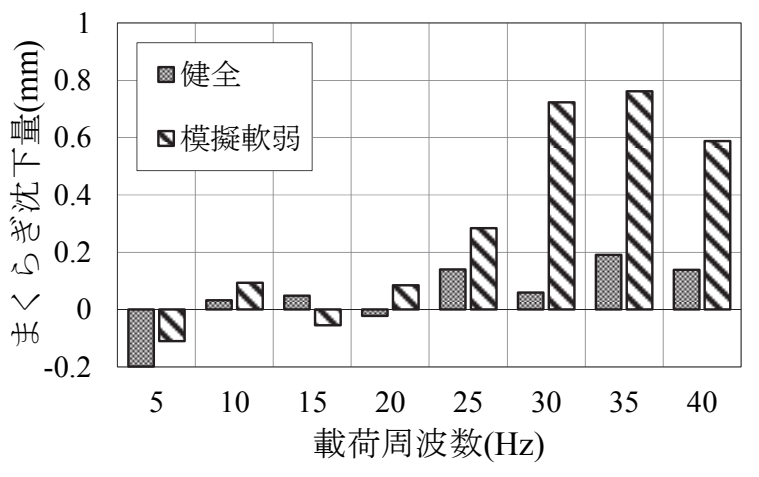

図-5 20,000回の載荷で生じたまくらぎ沈下量

レールとバラスト下層を比較しても加速度の減衰は小さ い. また，図一7を見ると健全路盤，模擬軟弱路盤とも軌 道各部の加速度波形に位相のずれはほとんどなく，概ね 同位相であることがわかる。 バラスト下層の加速度は, 路盤面直上で測定しているため, 路盤の上面加速度とほ ぼ等しいとみなせるとすると，模擬軟弱路盤上では路盤 上面からレールまでほとんど振動が減衰せず，一体に近 い形で振動していると考えられる。これらは東海道新幹 線本線において測定された軌道狂いの進行が見られる箇 所とそうでない箇所の応答の特徵8とも一致しており, 本試験は本線における現象を概ね再現できているといえ る. また，模擬軟弱路盤においてまくらぎ沈下量が急激 に増加した $25 \mathrm{~Hz}$ 以上のときの最大加速度を見ると，レ 一ルからバラスト下層まで軌道全体の加速度が重力加速 度より大きくなっている. 同様に健全路盤でまくらぎ沈 下量が微増した $35 \mathrm{~Hz}$ では，バラス卜上層の加速度が重 力加速度より大きくなっており，40 Hzになるとバラス 卜全体の加速度が重力加速度を上回っている.

バラスト下層の最大加速度とまくらぎ沈下量の関係を 図-8に示す．前述したようにバラスト下層の加速度は路 盤上面の加速度とほぼ等しいとみなせるので，図-8は路 盤加速度とまくらぎ沈下量の関係と表していると考えて 考察する. 路盤加速度が重力加速度以下のときは, 路盤 加速度とまくらぎ沈下量が概ね比例関係にあることがわ 


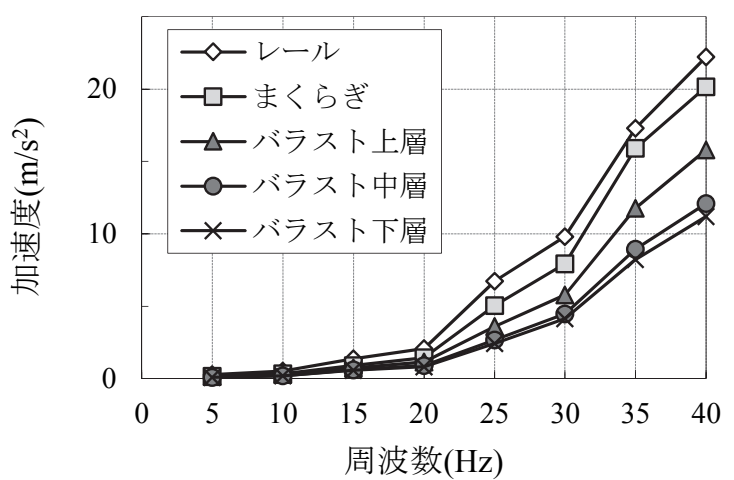

(a) 健全路盤

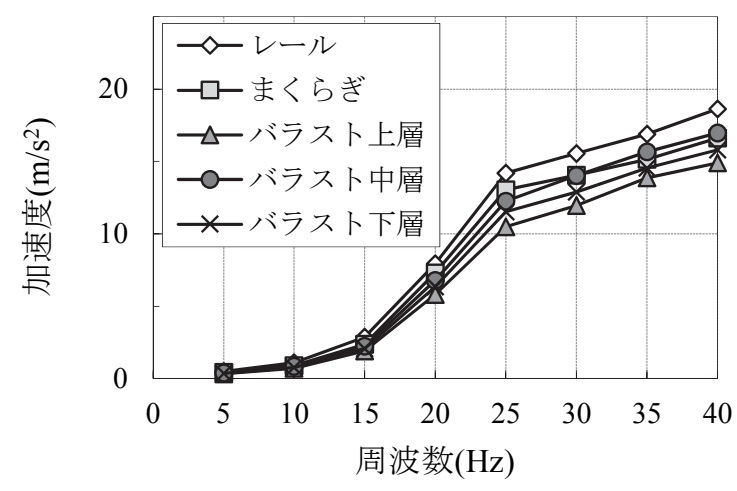

(b) 模擬軟弱路盤

図-6 軌道各部の最大加速度（鉛直下向き）

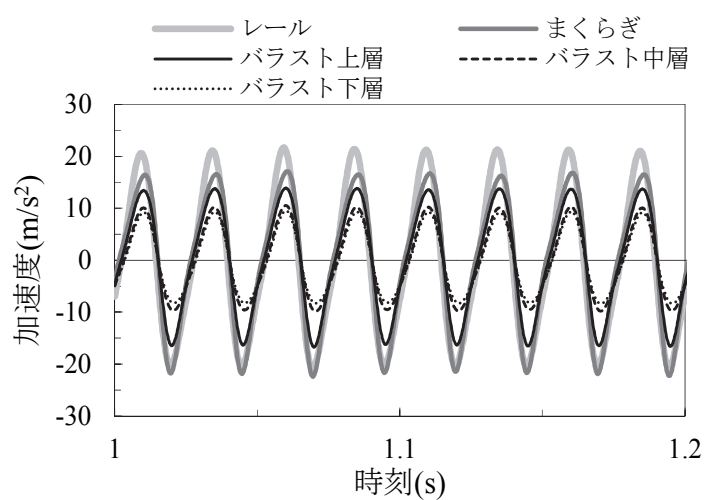

(a) 健全路盤

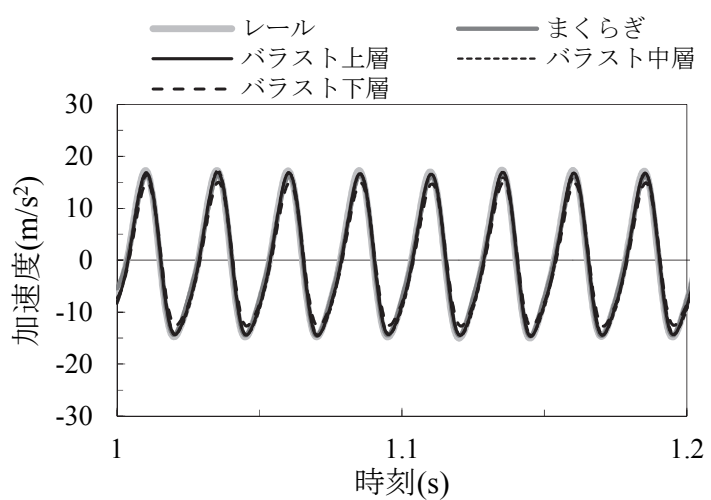

(b) 模擬軟弱路盤

図-7 軌道各部の加速度波形

かる. 路盤加速度が重力加速度以上になるとこの比例関 係がなくなり，まくらぎ沈下量の増加が著しくなる．ま た，さらに路盤加速度が増加するとまくらぎ沈下量は減 少傾向に転じる.

バラスト加速度が重力加速度に達したときの状況につ いて考える. バラストは主に上方のバラストの重量と粒 子間摩擦力によって周囲のバラストから拘束力を受け, バラスト層としての形状を維持している. 拘束している バラストに上向きの慣性力が生じると, 加速度に比例し てこれらの拘束力は減少することになる．これは既往の 研究にも示されている17. さらに加速度が増加しバラス 卜に作用する慣性力が重力以上になると，拘束力が完全 に失われて個々のバラスト粒子は非常に不安定な状態と なり，これが原因でまくらぎ沈下量の急激な増加が発生 したと考えられる.これらの現象について，第3章およ び第4章のシミュレーションによってさらに詳しく考察 する.

\section{b) 振動特性試験}

振動特性試験では, 起振台車を用いて試験軌道をラン ダム加振し, 各条件の軌道の振動特性を求めた. バラス ト下層部速度のパワースペクトル密度（以下，PSDとい う）を載荷荷重のPSDで除して求めたモビリティを図-9

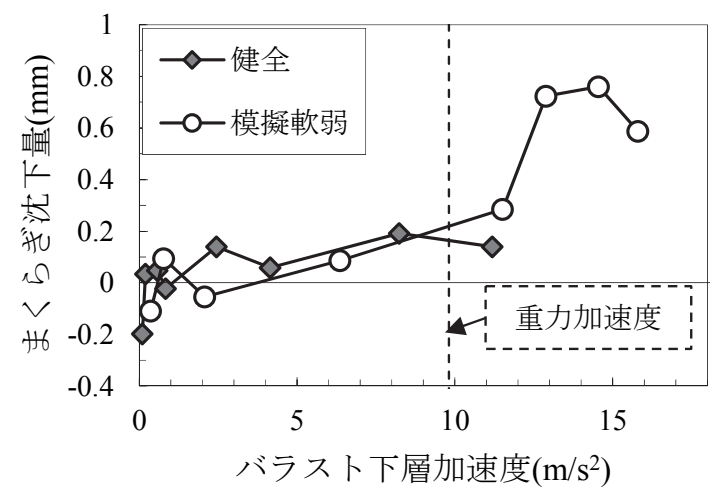

図-8 バラスト下層加速度とまくらぎ沈下量の関係

に示す（加速度の応答倍率であるアクセレランスおよび 変位の応答倍率であるコンプライアンスに関する考察は 本論文では割愛する，詳細は文献9を参照されたい）。 なお，10 Hz以下では加振時に発生した輪重および加速 度が非常に小さく, 測定時の誤差の影響が大きかったた め, 議論は $10 \mathrm{~Hz}$ 以上の領域で行うこととする.

モビリティがピークとなる周波数は, 健全路盤で41 $\mathrm{Hz}$ ，模擬軟弱路盤では $36 \mathrm{~Hz}$ であり，ピークより高い周 波数のモビリティは健全路盤では横ばいから微减傾向, 


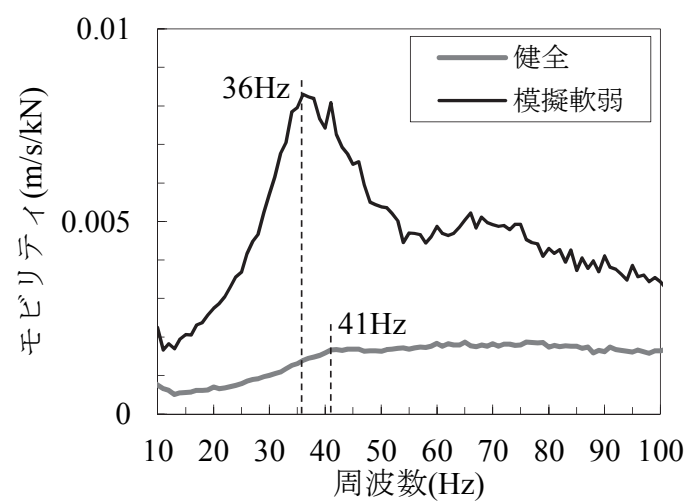

図-9 モビリティ

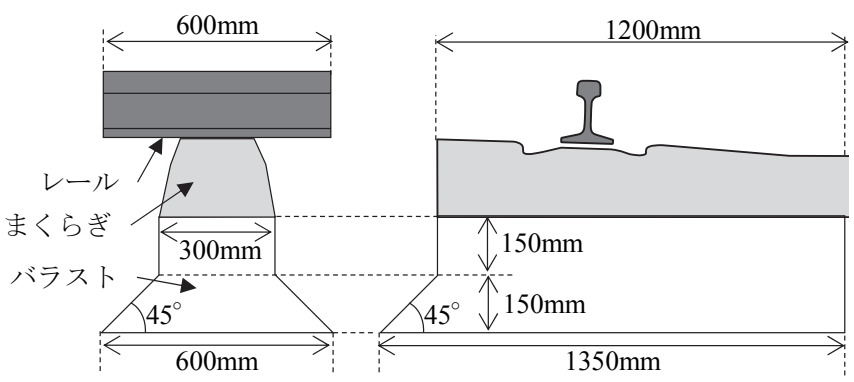

図-10 固有振動数計算時に考慮した軌道の範囲 ${ }^{18)}$
模擬軟弱路盤では減少傾向となっている.

モビリティに現れたこれらのピーク周波数について考 える. 図-7で示したように, 沈下特性試験において載荷 時に試験軌道全体が一体に近い形で振動していたことか ら，まくらぎからの荷重が伝達した範囲を図-1018)，表-2 に示したように仮定し, 本試験の軌道を 1 質点の振動系 と考える．なお，表-2中の路盤剛性は，本試験軌道にお ける静的載荷試験結果から求めたものである．試験軌道 の固有振動数は健全路盤で $44.5 \mathrm{~Hz}$ ，模擬軟弱路盤で 30.8 $\mathrm{Hz}$ となり，モビリティに現れたピーク周波数に概ね致している．また，ピーク周波数は繰返し載荷試験から 得られたまくらぎ沈下量が最大となる周波数（図-5）と も概ね一致する.

本試験の結果から，軌道はレール・まくらぎ・バラス 卜の合計質量と路盤岡性によって決まる固有振動数を有 しており，外力によるバラスト層の応答はこの固有振動 数で卓越すると考えられる，まくらぎ沈下量は，固有振 動数付近で軌道が加振されたときに応答が卓越したこと で増加したと考えられる. また, 固有振動数以上の周波 数領域も考慮した場合，載荷周波数とまくらぎ沈下量の 関係はモビリティと近い傾向を示すことがわかる.

\section{DEM による荷重の各作用が軌道沈下に与える 影響の考察}

本章では，軌道沈下のメカニズムを理論的に解明する ための基礎検討として載荷解析を行い，まくらぎから入 力される荷重に含まれる各作用がどのように軌道沈下に 影響しているかについて考察する.

まくらぎ上に繰返し荷重が作用するとき，沈下を引き 起こす荷重の作用には以下のものが考えられる. (1) 静 的荷重による沈下, (2) 静的荷重の繰返し作用による沈 下，(3) 動的荷重による沈下，(4) 路盤振動による沈下で ある。まくらぎ沈下に影響の大きい作用を明らかにする
表-2 固有振動数算出時の軌道諸元

\begin{tabular}{|c|c|c|}
\hline \multirow{2}{*}{ 項目 } & \multicolumn{2}{|c|}{ 路盤条件 } \\
\hline & 健全 & 模擬軟弱 \\
\hline レール質量 $(k g)$ & 36.5 & 36.5 \\
\hline まくらぎ質量(kg) & 130.0 & 130.0 \\
\hline バラスト質量(kg) & 244.5 & 244.5 \\
\hline 質量合計(kg) & 411.0 & 411.0 \\
\hline 路盤ばね岡性(MN/m) & 34.0 & 15.3 \\
\hline 固有振動数(Hz) & 44.5 & 30.8 \\
\hline
\end{tabular}

ことで，沈下を抑制する対策の方向性を明確にすること ができると考える，そこで本章では，解析を用いてこれ らの作用を可能な限り独立して作用させることで各作用 の影響度を明らかにする。解析にはバラスト層のような 粒状体の塑性変形を模擬できるDEMを用いる．DEMは 要素個々の挙動を再現できるため, このようなバラスト 層の沈下挙動を分析するのに適している. まくらぎの沈 下挙動に関しては，まくらぎの底面幅に対してまくらぎ 長さが8倍程度あるため，まくらぎ下のバラスト流動は まくらぎ断面方向への成分が大きいと考えられる. 加え て多数の条件で解析するためには計算負荷を抑える必要 もあるため, 本研究では2次元モデルで解析を行うこと とする.なお，解析には筑波大学で開発された 2 次元 DEM解析コード “DEM-seg” 19)を用いる.

\section{(1) 解析モデル}

本解析に用いた解析モデルを図-11 に示す．解析モデ

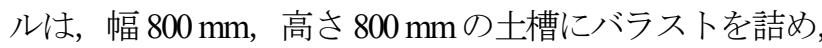
まくらぎ 1 本を設置したモデルとする. バラスト要素は 図-12 に示寸ように, バラスト粒子ひとつにつき円要素 2 個を用いてモデル化する．また，長軸・短軸比には 30 個のバラスト寸法を計測した值の平均を用いる. バラス 卜要素のモデル化方法は解析に要する時間に大きく影響 を与える. 既往の研究 20)では 3 次元モデルにおいて球要 素 10 個を用いてバラスト粒子をモデル化している例が あるが，これに準じて円要素 10 個でバラスト要素モデ 


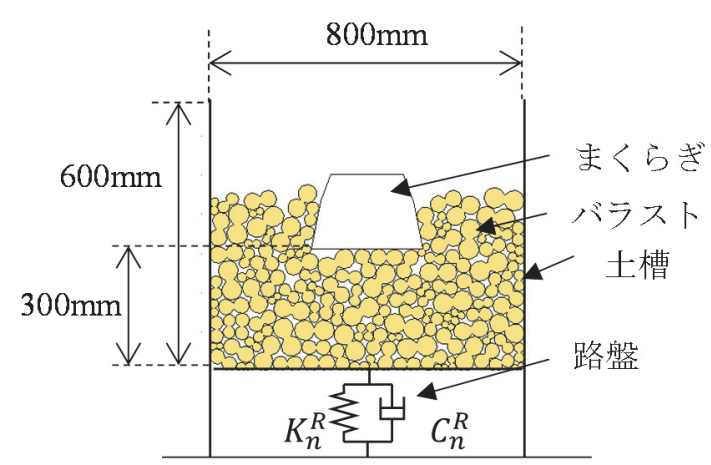

図-11 解析モデル

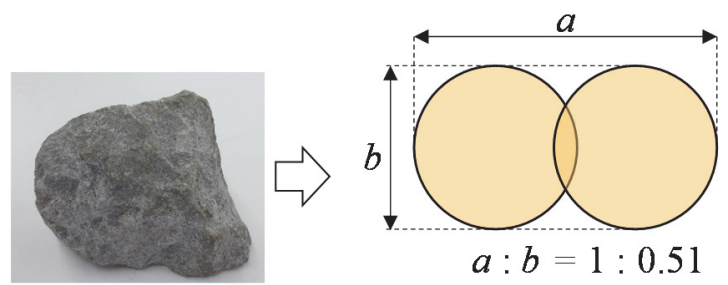

図-12 バラストモデル

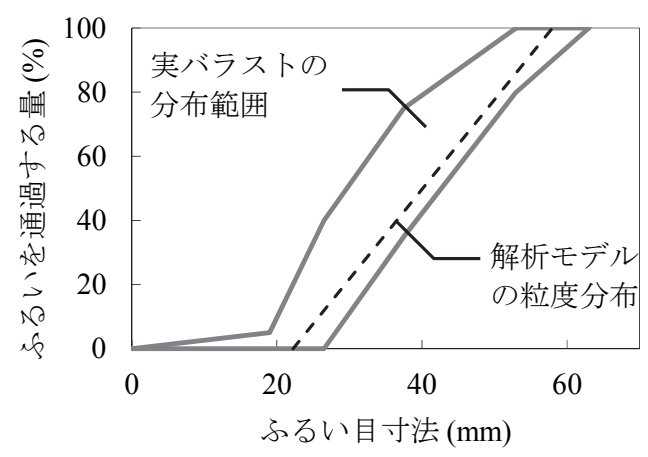

図-13＼cjkstart解析モデルのバラスト粒度分布

ルを作成すると計算負荷が膨大になり，数千回規模の繰 返し載荷をさまざまな条件で実施するのは困難である. 本研究では, 多数のパターンで数千回オーダーの繰返し 載荷解析を実施することで軌道の沈下に影響する因子と そのときのバラスト詳細挙動を明らかにすることが目的 である. そのため, バラスト層の形状を維持可能であり, かつ最も計算負荷を小さくできる円要素 2 個でモデル化 したバラスト要素を用いることとする．DEM における 各要素の接触は，法線方向がばねおよびダンパー，接線 方向がばね，ダンパーおよびスライダーを用いてモデル 化されている，接触力はこれらのばねで再現されるが， バラスト粒子の破砕は考慮していない. 解析で各要素に 用いた主なパラメーターを表-3に示す，なお，本モデル ではバラスト 1 個分の奥行きを考慮しているため, 各要 素の接触に関するパラメーターについては既往の研究 20) を参考に 3 次元モデルで適用されている值と同一とした. また，土槽の底面は鉛直方向のばねおよびダンパーで支
表-3 解析諸元

\begin{tabular}{|c|c|c|c|c|}
\hline & \multicolumn{2}{|c|}{ 項目 } & \multicolumn{2}{|r|}{ 值 } \\
\hline \multirow{7}{*}{$\begin{array}{l}\text { ま } \\
\vdots \\
\vdots \\
\text { ぎ }\end{array}$} & 密度 $\left(\mathrm{g} / \mathrm{cm}^{3}\right)$ & & $\rho^{S}$ & 2.50 \\
\hline & 質量 $(\mathrm{kg})$ & & $m^{s}$ & 7.92 \\
\hline & \multirow{2}{*}{$\begin{array}{l}\text { ばね将数 } \\
(\mathrm{N} / \mathrm{m})\end{array}$} & 法線方向 & $K_{n}^{S}$ & $9.09 \times 10^{6}$ \\
\hline & & 接線方向 & $K_{s}^{S}$ & $2.27 \times 10^{6}$ \\
\hline & \multirow{2}{*}{$\begin{array}{l}\text { 減衰係数 } \\
(\mathrm{N} \cdot \mathrm{s} / \mathrm{m})\end{array}$} & 法線方向 & $C_{n}^{S}$ & 652 \\
\hline & & 接線方向 & $C_{s}^{S}$ & 326 \\
\hline & \multicolumn{2}{|c|}{ 粒子間摩擦角 (degree) } & $\mu^{s}$ & 20 \\
\hline \multirow{7}{*}{$\begin{array}{l}\text { バ } \\
\text { ス } \\
\text { ト }\end{array}$} & \multicolumn{2}{|c|}{ 密度 $\left(\mathrm{g} / \mathrm{cm}^{3}\right)$} & $\rho^{B}$ & 2.50 \\
\hline & \multicolumn{2}{|l|}{ 質量 $(k g)$} & 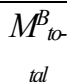 & 54.2 \\
\hline & \multirow{2}{*}{$\begin{array}{l}\text { ばね定数 } \\
(\mathrm{N} / \mathrm{m})\end{array}$} & 法線方向 & $K_{n}^{B}$ & $9.09 \times 10^{6}$ \\
\hline & & 接線方向 & $K_{s}^{B}$ & $2.27 \times 10^{6}$ \\
\hline & \multirow{2}{*}{$\begin{array}{l}\text { 減衰係数 } \\
(\mathrm{N} \cdot \mathrm{s} / \mathrm{m})\end{array}$} & 法線方向 & $C_{n}^{B}$ & 652 \\
\hline & & 接線方向 & $C_{s}^{B}$ & 326 \\
\hline & \multicolumn{2}{|c|}{ 粒子間摩擦角 (degree) } & $\mu^{B}$ & 36 \\
\hline \multirow{6}{*}{ 蓸 } & \multirow{2}{*}{$\begin{array}{l}\text { ばね定数 } \\
(\mathrm{N} / \mathrm{m})\end{array}$} & 法線方向 & $K_{n}^{B o}$ & $9.09 \times 10^{6}$ \\
\hline & & 接線方向 & $K_{s}^{B o}$ & $2.27 \times 10^{6}$ \\
\hline & \multirow{2}{*}{$\begin{array}{l}\text { 減衰係数 } \\
(\mathrm{N} \cdot \mathrm{s} / \mathrm{m})\end{array}$} & 法線方向 & $C_{n}^{B o}$ & 652 \\
\hline & & 接線方向 & $C_{s}^{B o}$ & 326 \\
\hline & \multirow{2}{*}{$\begin{array}{l}\text { 粒子間摩擦角 } \\
\text { (degree) }\end{array}$} & 側面 & $\mu^{B o}$ & 0 \\
\hline & & 底面 & $\mu^{B o}$ & 20 \\
\hline \multirow{2}{*}{$\begin{array}{l}\text { 路 } \\
\text { 盤 }\end{array}$} & ばね定数 $(\mathrm{N} / \mathrm{m})$ & 法線方向 & $K_{n}^{R}$ & $5.94 \times 10^{6}$ \\
\hline & 減衰係数 $(\mathrm{N} \cdot \mathrm{s} / \mathrm{m}$ & 法線方向 & $C_{n}^{R}$ & $4.98 \times 10^{4}$ \\
\hline
\end{tabular}

持されており, まくらぎからの加振によって生じる路盤 振動を再現できるようにした. 本モデルでは, 詳細な路 盤の変形を再現できてはいないが，まくらぎ直下付近に おける路盤振動とバラスト振動との関係を定性的に把握 するため, このようなモデルとした.

解析モデルの作成時は，図-13 に示寸粒度分布でバラ スト粒子を準備し，土槽内に自由落下させたのち，一時 的にバラスト粒子の摩擦係数を 0 とすることで $300 \mathrm{~mm}$ 厚さの締固められたバラスト層の状態を再現した. この バラスト層の上にまくらぎを設置し，最後にまくらぎ側 方にバラストを投下したものを初期状態とした.

\section{（2）静的荷重の影響}

\section{a) 解析条件}

図-11に示した解析モデルにおいて，まくらぎ要素に 単調圧縮荷重を変位制御により作用させた．動的影響が 排除できていることを確認するため, 載荷速度はまくら ぎが $1.0 \mathrm{~mm} / \mathrm{s} ， 0.1 \mathrm{~mm} / \mathrm{s}$ で沈下する2種類を設定した.

\section{b) 解析結果}

解析から得られたまくらぎの荷重一変位関係を図-14 に示寸. 載荷速度が $1.0 \mathrm{~mm} / \mathrm{s}, 0.1 \mathrm{~mm} / \mathrm{s}$ でグラフの傾きに 差がないことから，動的影響は十分排除されているとい える.また，載荷速度が小さいほうが最大荷重はやや大 


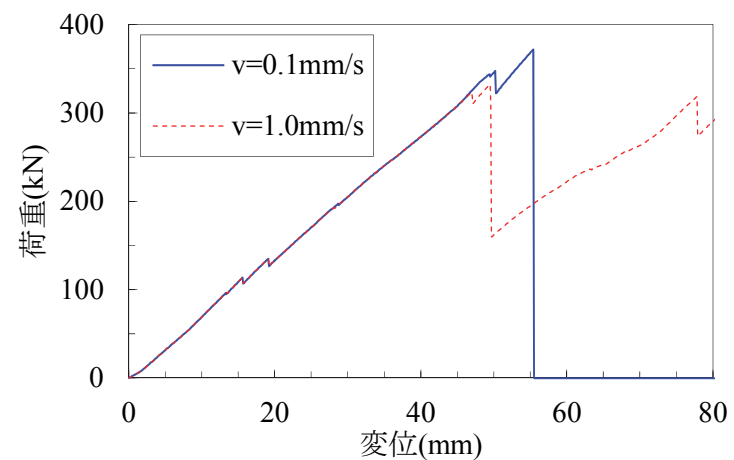

図-14 まくらぎの荷重一変位関係（単調圧縮解析）

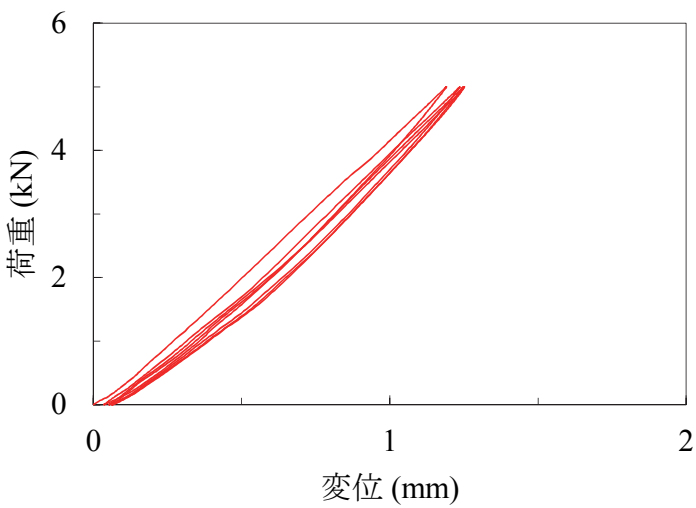

図-15 まくらぎの荷重一変位関係（準静的繰返し載荷解析）

表-4 まくらぎの残留変位（準静的繰返し載荷解析）

\begin{tabular}{c|rrrrrrr}
\hline $\begin{array}{c}\text { 載荷回数 } \\
\text { (回) }\end{array}$ & 1 & 3 & 5 & 7 & 9 & 10 & 20 \\
\hline $\begin{array}{c}\text { 残留変位 } \\
(\mathrm{mm})\end{array}$ & 0.04 & 0.06 & 0.07 & 0.07 & 0.08 & 0.08 & 0.08 \\
\hline
\end{tabular}

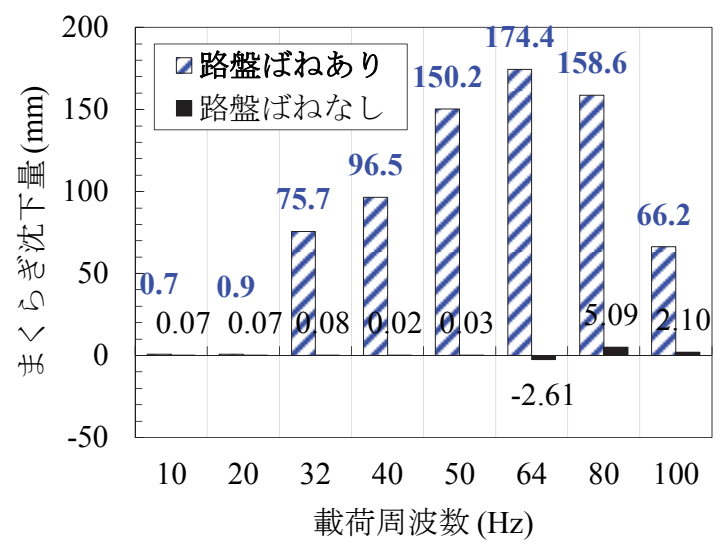

図-16 5,000回載荷後のまくらぎ沈下量 （動的繰返し載荷解析）

きい，最大荷重が小さい載荷速度 $1.0 \mathrm{~mm} / \mathrm{s}$ の場合で，最 大荷重は344kNである．前章で実施した試験の荷重条件 を本 2 次元モデルでの荷重に換算すると約 $3 \mathrm{kN}$ となり, 静的強度から見ると列車荷重を想定した載荷はごく小さ い荷重領域でのものであることがわかる。つまり，本解
土木学会論文集A1 (構造・地震工学), Vol. 75, No. 1, 1-16, 2019.

析で列車荷重程度の静的荷重を入力してもまくらぎの大 きな沈下やバラスト層の崩壊は発生しないといえる.

（3）静的荷重の繰返し作用の影響

a) 解析条件

図-11に示したモデルにおいて，まくらぎ要素に準静 的な繰返し載荷を実施する. 動的要素を極力排除するた め載荷周波数を $0.025 \mathrm{~Hz}$ とする。.また，最大荷重を $5.0 \mathrm{kN}$, 載荷回数を20回とする.

\section{b) 解析結果}

載荷 1回目から4回目までの荷重一変位曲線を図-15に 示寸. 載荷時の変位増加量に比べて除荷時の変位減少量 が小さく, 荷重一変位曲線はわずかなヒステリシスを描 く．これは実際のバラスト層に載荷した場合にも生じる 現象であり ${ }^{211}$ ，実現象と同様の傾向を示したといえる. 実際の軌道では路盤部も非線形な傾向を示すが，本モデ ルでは路盤ばねモデルが線形であるため，路盤部の非線 形性は現れない，そのため，実際の軌道よりもまくらぎ 変位の非線形性は小さいと考えられる。また，20 回の 繰返し載荷において完全に除荷された時の残留変位を表 -4 に示寸. 繰返し荷重に対して 1 回目に $0.04 \mathrm{~mm}$ の残留 変位が発生したが，それ以降は 1 回の載荷あたりの残留 変位増加量は $0.01 \mathrm{~mm}$ 以下であり, 載荷 9 回目以降は残 留変位は増加していない，したがって，本解析では準静 的な繰返し荷重は軌道沈下にはほとんど影響しないとい える.

\section{（4）動的荷重の影響 \\ a) 解析条件}

まくらぎからの動的荷重の影響を検証するため，図11に示したモデルと，床面を支持する路盤ばねおよび 減衰要素の作用を停止し路盤を固定した状態のモデルで 動的繰返し載荷解析を実施する．荷重条件は $2.0 \pm 1.4 \mathrm{kN}$, 載荷周波数は $10 ， 20 ， 32 ， 40 ， 50 ， 64 ， 80,100 \mathrm{~Hz}$ ，載 荷回数はいずれも 5,000 回とする.

\section{b) 解析結果}

解析から得られたまくらぎ沈下量を図-16に示す．路 盤ばねがあり，路盤面に振動が発生する条件では，32 $\mathrm{Hz}$ から $100 \mathrm{~Hz}$ での加振時にまくらぎ沈下が発生している のに対し，路盤を固定した条件ではまくらぎ沈下はほと んど発生していない，これは，路盤を固定した場合，ま くらぎからの振動はまくらぎ直下およびその付近のバラ ストのみに伝達し，かつ固定された路盤までにバラスト の振動が低減されるのに対し，路盤ばねがある場合は， まくらぎからの入力で路盤に生じる振動により， バラス 卜全体が下方から加振されることで，バラストが流動し やすい状況が生じるためと考えられる. そのため, まく らぎから動的荷重を入力しても路盤振動が生じなければ まくらぎ沈下はほとんど生じない. 
表-5 路盤の動的影響検証時の解析条件

\begin{tabular}{|c|c|c|c|c|c|c|c|c|c|c|}
\hline \multirow{3}{*}{$\begin{array}{c}\text { 解析厅ース } \\
\text { 名称 }\end{array}$} & \multirow{3}{*}{$\begin{array}{c}\text { 加速度 } \\
\text { 振幅 } \\
\left(\mathrm{m} / \mathrm{s}^{2}\right)\end{array}$} & \multicolumn{9}{|c|}{ 載荷周波数 $(\mathrm{Hz})$} \\
\hline & & 5 & 10 & 20 & 32 & 40 & 50 & 64 & 80 & 100 \\
\hline & & \multicolumn{9}{|c|}{ 変位振幅(mm) } \\
\hline $5 \mathrm{~m} / \mathrm{s}^{2}$ & 5 & 5.061 & 1.273 & 0.318 & 0.124 & 0.080 & 0.051 & 0.030 & 0.025 & 0.020 \\
\hline $10 \mathrm{~m} / \mathrm{s}^{2}$ & 10 & 10.122 & 2.531 & 0.637 & 0.249 & 0.159 & 0.102 & 0.062 & 0.052 & 0.040 \\
\hline $20 \mathrm{~m} / \mathrm{s}^{2}$ & 20 & 15.183 & 3.804 & 0.947 & 0.373 & 0.239 & 0.153 & 0.092 & 0.077 & 0.060 \\
\hline $30 \mathrm{~m} / \mathrm{s}^{2}$ & 30 & 20.276 & 5.061 & 1.265 & 0.492 & 0.318 & 0.204 & 0.124 & 0.102 & 0.080 \\
\hline $40 \mathrm{~m} / \mathrm{s}^{2}$ & 40 & 25.337 & 6.334 & 1.584 & 0.617 & 0.394 & 0.255 & 0.154 & 0.130 & 0.099 \\
\hline $50 \mathrm{~m} / \mathrm{s}^{2}$ & 50 & 30.399 & 7.592 & 1.902 & 0.741 & 0.473 & 0.302 & 0.187 & 0.155 & 0.119 \\
\hline $60 \mathrm{~m} / \mathrm{s}^{2}$ & 60 & 40.521 & 10.138 & 2.531 & 0.990 & 0.633 & 0.404 & 0.246 & 0.207 & 0.159 \\
\hline
\end{tabular}

\section{（5）路盤振動の影響}

\section{a) 解析条件}

前節でまくらぎ沈下量には路盤面の振動の影響が大き いことが推察されるため，ここでは図-11に示したモデ ルにおいて，まくらぎに静荷重を $2.0 \mathrm{kN}$ 作用させた状態 で路盤要素のみを強制的に振動させる. 加振条件は表-5 に示すとおり，合計63通りの周波数・変位振幅の組み合 わせで解析を実施する。

\section{b) 解析結果}

解析から得られた路盤部の振動とまくらぎ沈下量の関 係を図-17から図-19に示す。いずれの図においても，一 定の路盤振動が発生すると，まくらぎ沈下量が非常に大 きくなることがわかる．本解析結果から，まくらぎの沈 下に対して, 路盤面の振動の影響が極めて大きいといえ る. 実現象では車両の走行によりまくらぎからバラスト に対して振動が入力されているが，バラスト層の沈下に 支配的に影響を与えるのはまくらぎからの入力によって 生じる路盤振動であると考えられる.

また，図-17を見ると路盤加速度が $10 \mathrm{~m} / \mathrm{s}^{2}$ 以下の条件で はまくらぎ沈下はほとんど発生していない. よって，路 盤加速度が $10 \mathrm{~m} / \mathrm{s}^{2}$ （三重力加速度）を上回ることがまく らぎ沈下発生の必要条件になっている. 沈下が発生した 路盤加速度 $15 \mathrm{~m} / \mathrm{s}^{2}$ 以上の条件を見ると, 加速度とまくら ぎ沈下量との間に相関はあまり見られない.一方，図18, 図-19を見ると，同様にまくらぎ沈下発生の閾值が あるほか，その後も路盤速度，あるいは変位とまくらぎ 沈下量との間に一定の相関が見られる.この相関につい ては次章で考察する.

\section{DEMによる軌道の繰返し載荷解析}

前章の解析結果からも，載荷試験で得た結果と同様に 路盤振動が軌道沈下量に大きく影響する可能性が高いこ とが明らかとなった，そこで本章では，引き続き路盤振 動を考慮した解析モデルを用いて繰返し載荷解析を行い, まくらぎ沈下量と路盤応答の関係について考察する.

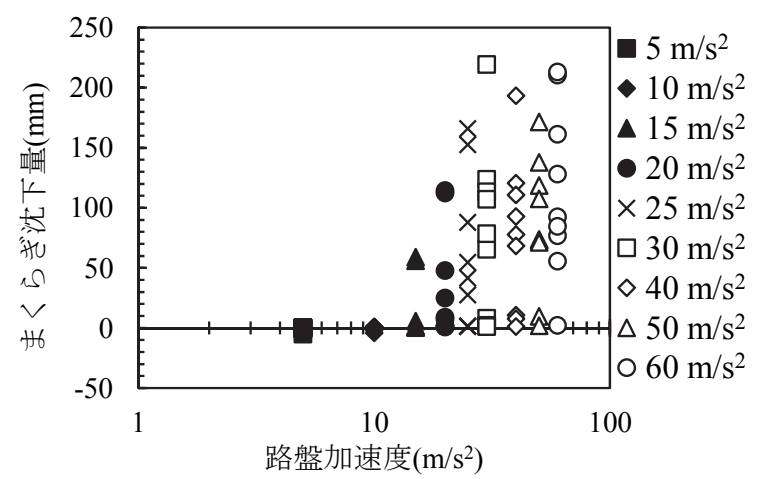

図-17＼cjkstart路盤加速度一まくらぎ沈下量関係 (路盤強制振動解析)

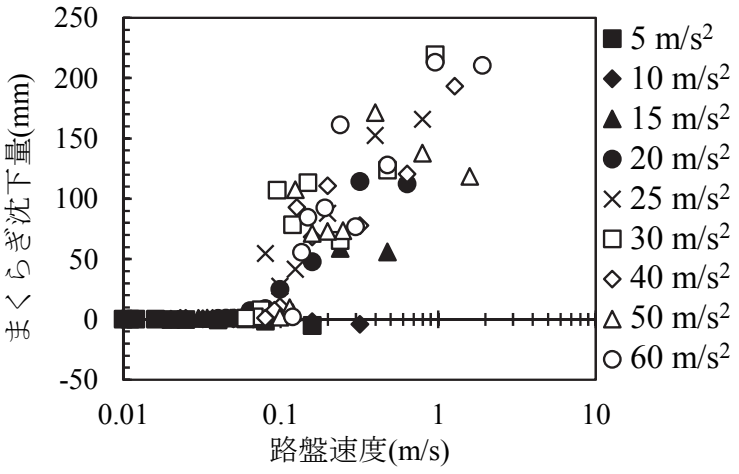

図-18＼cjkstart路盤速度一まくらぎ沈下量関係 （路盤強制振動解析）

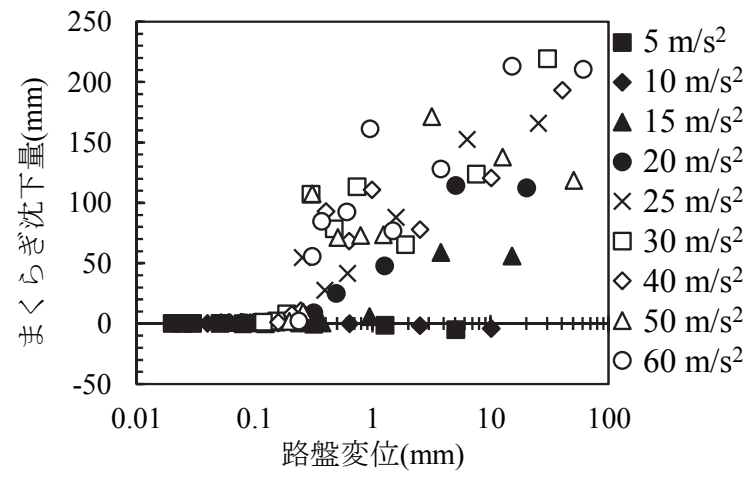

図-19＼cjkstart路盤変位一まくらぎ沈下量関係 （路盤強制振動解析） 
表-6 繰返し載荷解析における解析モデルの路盤条件

\begin{tabular}{lc|rrr}
\hline \multicolumn{1}{c|}{ 項目 } & \multicolumn{1}{c}{ Roadbed-A } & \multicolumn{1}{c}{ Roadbed-B } & \multicolumn{1}{c}{ Roadbed-C } \\
\hline 地盤反力係数 $\left(\mathrm{MN} / \mathrm{m}^{3}\right)$ & $K_{30}$ & 30 & 50 & 110 \\
ばね怔数 $(\mathrm{N} / \mathrm{m})$ & $K_{n}^{R}$ & $1.62 \times 10^{6}$ & $2.70 \times 10^{6}$ & $5.94 \times 10^{6}$ \\
減衰係数 $(\mathrm{N} ・ \mathrm{~s} / \mathrm{m})$ & $C_{n}^{R}$ & $1.36 \times 10^{4}$ & $2.26 \times 10^{4}$ & $4.98 \times 10^{4}$ \\
1 質点振動系における固有振動数 $(\mathrm{Hz})$ & $f$ & 38.7 & 50.0 & 74.1 \\
\hline
\end{tabular}

表-7 解析条件

\begin{tabular}{lrrrrrr}
\hline シリーズ名 & $\begin{array}{c}\text { 荷重条件 } \\
(\mathrm{kN})\end{array}$ & $\begin{array}{c}\text { 最大荷重 } \\
(\mathrm{kN})\end{array}$ & $\begin{array}{c}\text { 最小荷重 } \\
(\mathrm{kN})\end{array}$ & $\begin{array}{c}\text { 載荷周波数 } f \\
(\mathrm{~Hz})\end{array}$ & $\begin{array}{c}\text { 路盤岡性 } K \\
\left(\mathrm{MN} / \mathrm{m}^{3}\right)\end{array}$ & $\begin{array}{r}\text { 合計解析 } \\
\text { パターン数 }\end{array}$ \\
\hline $\mathrm{P} 20-140-f-K$ & $2.0 \pm 1.4$ & 3.4 & 0.6 & $10,20,32,40,50,64,80,100$ & $30(\mathrm{~A}), 50(\mathrm{~B}), 110(\mathrm{C})$ & 24 \\
$\mathrm{P} 10-070-f-K$ & $1.0 \pm 0.7$ & 1.7 & 0.3 & $10,20,32,40,50,64,80,100$ & $30(\mathrm{~A}), 50(\mathrm{~B}), 110(\mathrm{C})$ & 24 \\
$\mathrm{P} 05-035-f-K$ & $0.5 \pm 0.35$ & 0.85 & 0.15 & $10,20,32,40,50,64,80,100$ & $30(\mathrm{~A}), 50(\mathrm{~B}), 110(\mathrm{C})$ & 24 \\
\hline
\end{tabular}

\section{(1) 解析モデル}

解析モデルは前章と同一 (図-11) とし，路盤条件は3 種類とした．路盤のパラメーター設定にあたっては，ま くらぎからの荷重伝達範囲を図-10 に示寸とおり仮定し てばね定数および咸衰係数を設定した。ばね定数は，地 盤反力係数がそれぞれ $30 \mathrm{MN} / \mathrm{m}^{3}$ (Roadbed-A), $50 \mathrm{MN} / \mathrm{m}^{3}$ (Roadbed-B), $110 \mathrm{MN} / \mathrm{m}^{3}$ (Roadbed-C)相当となるように設 定し，減衰係数は文献 4 -で設定された減衰係数相当を健 全路盤(Roadbed-C)と仮定して算出し, 他の条件は線形配 分とした. 路盤に用いるパラメーターを表-6に示す.

\section{（2）解析条件}

載荷荷重のパラメーターは荷重振幅，最大（最小）荷 重, 載荷周波数とし，これらを表-7に示すように設定す る. P20-140-f-Kにおける最大荷重 $3.4 \mathrm{kN}$ は，奥行きを考 慮した 3 次元に換算すると約 $68 \mathrm{kN}$ であり, 実物の新幹 線車両の車輪がまくらぎ直上にあるときに作用する静止 輪重の 2.3 倍程度に相当寸る. 軌道狂い等によって発生 する輪重の変動分を考慮して設定した．このほか 2 種類 の荷重条件を設定する. 解析ケースの総数は 72 , また, 各ケースにおける載荷回数は 5,000 回とする.

\section{(3) 解析結果}

\section{a) まくらぎ沈下曲線}

P10- 070- $f-K$ シリーズの解析から得られたまくらぎ沈 下曲線を図-20 に示寸．いずれの路盤条件でも，まくら ぎ沈下量は載荷周波数によって大きく異なっていること がわかる．また，まくらぎ沈下は一定の速度では進行せ ず，非線形な傾向を示している．詳しく見ると，比較的 線形な沈下の他, 停滞，急激な沈下が 5,000 回の載荷中 に不規則に発生している. また，ひとつのケースの中で もまくらぎ沈下曲線の傾きが途中で変化しているものも ある.これは，まくらぎ沈下の進行に伴い，バラストの 配置が刻々と変化する中で，一時的に安定的なバラスト

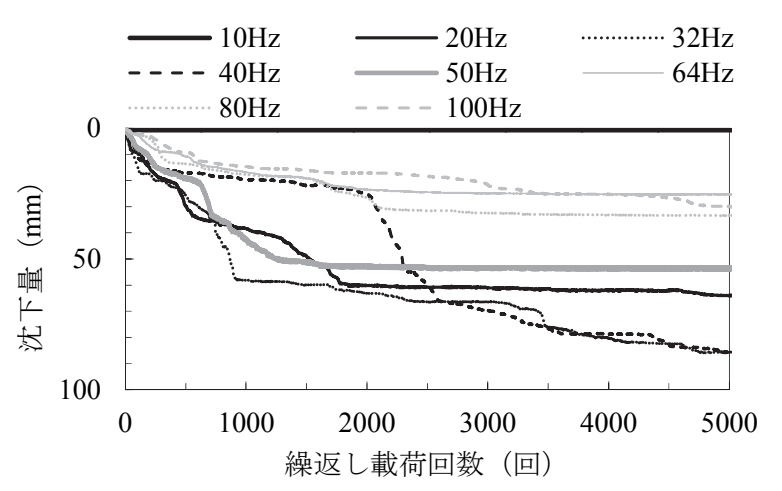

(a) Roadbed-A

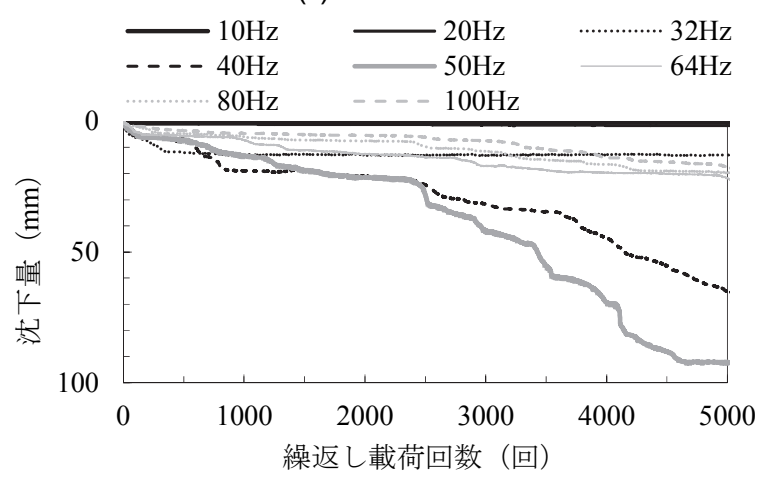

(b) Roadbed-B

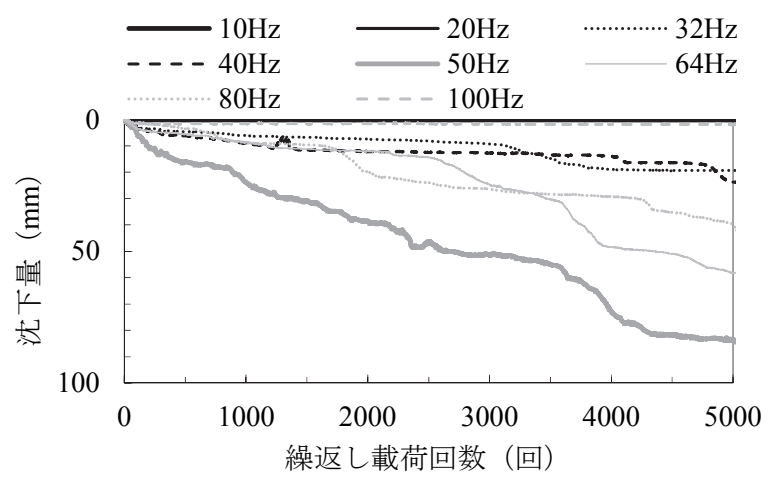

(c) Roadbed-C

図-20 まくらぎ沈下曲線(P10-070- $f$ - Kシリーズ) 


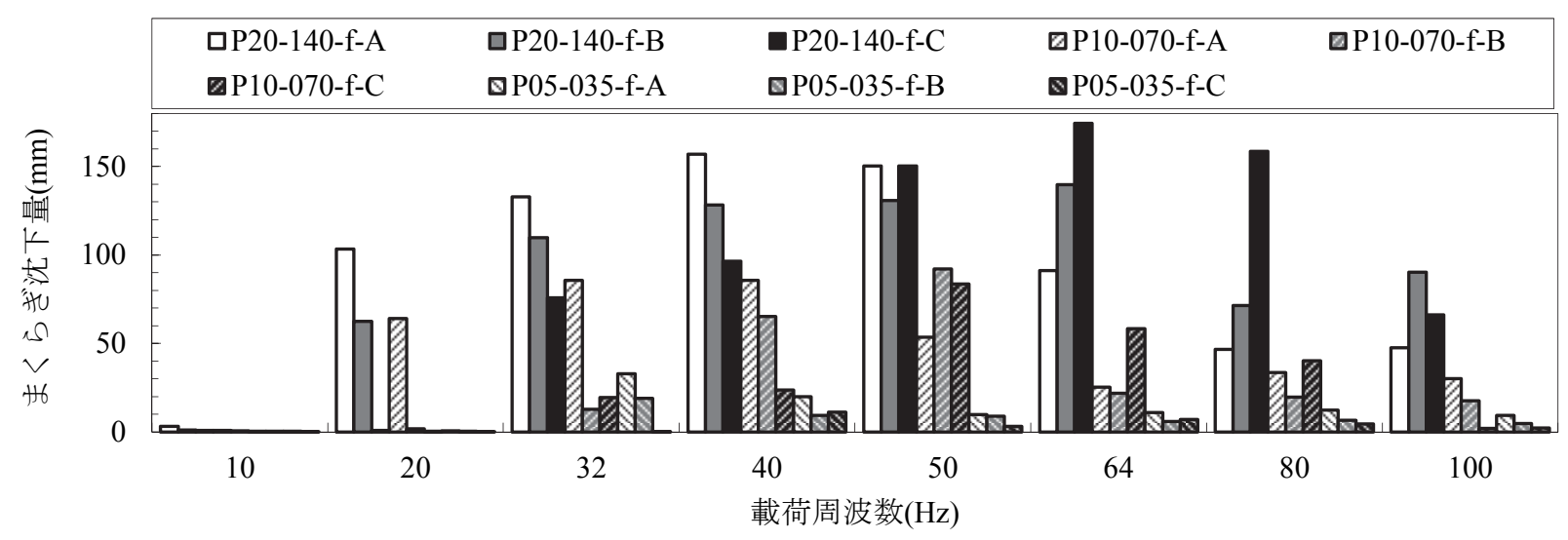

図-21 解析から得られた 5,000 回載荷後のまくらぎ沈下量

配置と不安定なバラス卜配置が生じているためであると 考えられる. 本モデルは 2 次元モデルであり，まくらぎ 長手方向（解析モデル奥行き方向）に 1 層分しかバラス 卜層を考慮していないため, バラスト層が非常に不安定 になったときに急激に沈下が生じることがあるが，実際 のバラスト層ではある断面でこのような現象が発生する とまくらぎ長手方向の他の断面がまくらぎからの荷重を 受けるようになるため, 全体としてこのような急激な沈 下に至る可能性は低い。しかしながら，バラスト軌道の 沈下は微視的には非線形的な要素を多く含む複雑な挙動 であることが本解析結果からわかる.

\section{b) まくらぎ沈下量と路盤応答}

各載荷周波数における，5,000 回加振後に生じたまく らぎ沈下量を図-21に示す. 載荷周波数が $40 \mathrm{~Hz}$ 以下の条 件では，載荷荷重および載荷周波数が同一のときに，概 ね路盤岡性が小さいほうが軌道沈下量が大きくなってい る.これは, 既往の研究で述べられている傾向 2)とも一 致している. しかし，載荷周波数が $50 \mathrm{~Hz}$ 以上の条件で はこの関係は成立しなくなっている，また，載荷周波数 と路盤剛性が同一のときには, 荷重振幅が大きいほどま くらぎ沈下量が大きくなっている.

載荷周波数について見ると，各条件において載荷周波 数 $10 \mathrm{~Hz}$ のときはいずれもほとんどまくらぎ沈下が発生 しておらず，20Hzまたは $32 \mathrm{~Hz}$ に載荷周波数が増加する と急激にまくらぎ沈下量が増加している。 この結果から は，まくらぎ沈下の発生有無に関して，境界となる条件 が存在すると考えられる。この境界となる条件について は後ほど詳しく述べる。 この境界を超えて発生し始める まくらぎ沈下は, 載荷周波数の増加に伴い増加傾向を示 寸が，載荷周波数が一定以上になると減少に転じている。 各条件でそれぞれ沈下量がピークとなる周波数を有して おり，これらは路盤条件ごとに異なる值を示している.

載荷周波数と路盤面の加速度振幅, 速度振幅, 変位振 幅の関係を図-22，図-23，図-24にそれぞれ示す．図-22,

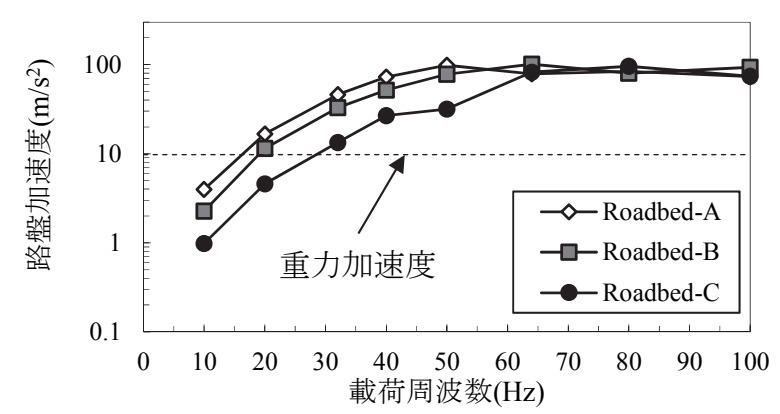

図-22 載荷周波数一路盤加速度関係(P20-140- $f-K$ シリーズ)

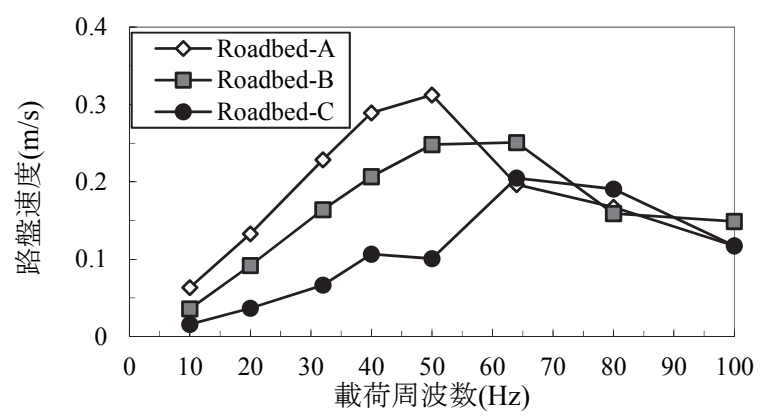

図-23載荷周波数一路盤速度関倸(P20-140- $f-K$ シリーズ)

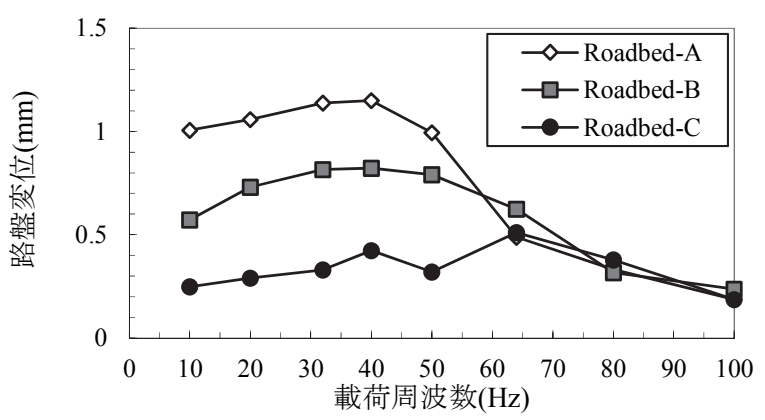

図-24 載荷周波数一路盤変位関係(P20-140- $f-K$ シリーズ) 


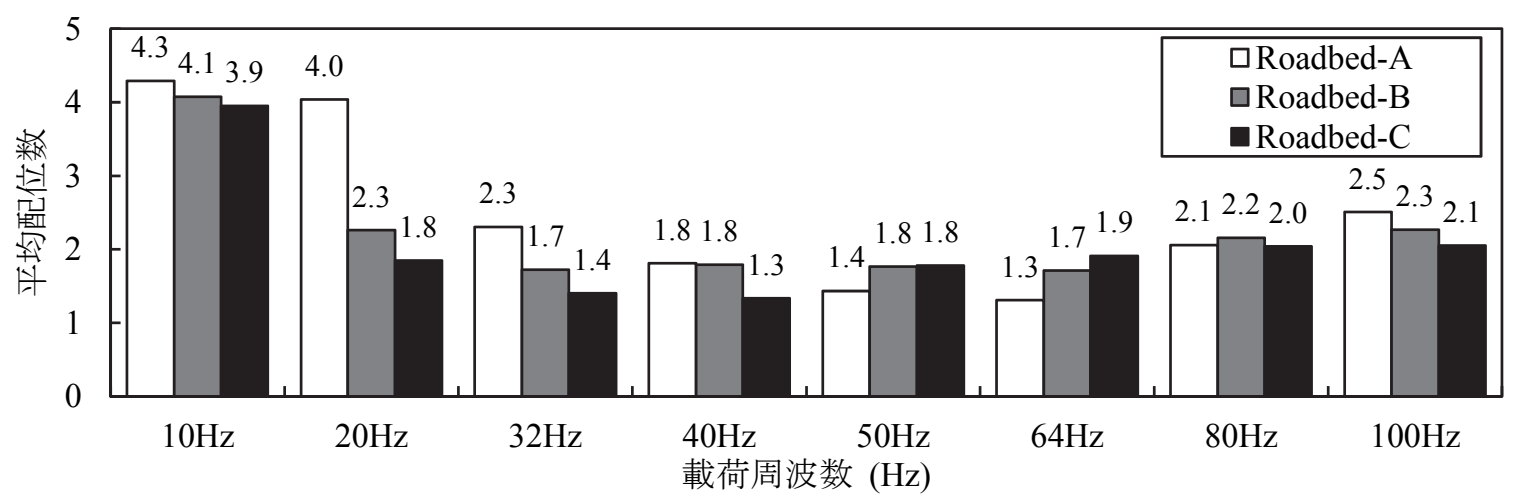

図-25 バラスト要素の平均配位数 (P10-070- $f-K$ ハリーズ)

図-23，図-24において，縦軸はそれぞれ路盤加速度振幅， 路盤速度振幅, 路盤変位振幅を示しており, 横軸は載荷 周波数を示している. 路盤応答は載荷開始直後を除いて 概小安定していたため, 路盤の応答值は載荷 4,000 回目 から5,000回目の間の平均值を用いている. 図-21, 図-22 を見ると，いずれの条件においてもまくらぎ沈下量が急 激に増加した周波数が，路盤加速度振幅が重力加速度以 上となった載荷周波数と一致していることが分かる。 ま た, 路盤加速度は載荷周波数の増加に伴って, 概礽増加 傾向またはほぼ横ばいの傾向を示している，一方，図23，図-24 を見ると路盤速度および路盤変位は載荷周波 数の増加に伴って前述したピーク周波数で緩やかなピー クを示した後，減少傾向となっている.

まず，解析結果に見られた，まくらぎ沈下発生有無の 境界となる条件について考える. 各条件での加振時のバ ラスト粒子の平均配位数を図-25に示寸，バラス卜粒子 の平均配位数は路盤加速度が重力加速度未満のときが 4 以上であるのに対し，重力加速度以上のときは2程度に 減少している. 配位数が 3 未満のときはバラストの支持 状態としては非常に不安定であるといえる.

バラスト粒子は周囲に隣接する粒子から拘束されて安 定な状態を維持しているが, バラストに振動が与えられ るとその加速度による慣性力が作用し，慣性力に比例し て拘束力が低下寸ることになる，そのため既往の研究で も示されているように の，バラストの加速度に比例して まくらぎ沈下量が大きくなる。このときは，周囲のバラ ストからの拘束力は低下寸るものの, 配位数はほとんど 変化しないと考えられる. これに対し，バラストに作用 する加速度が重力加速度以上になると，慣性力が物体力 を上回るため周囲のバラストの接触が失われる瞬間が発 生する.このように，バラスト加速度が重力加速度を超 えることでバラストの状態が大きく変化するため, 解析 結果のようなまくらぎ沈下量の急激な増加が生じたと考 えられる. 本解析では，土槽の壁面の摩擦係数を 0 に設 定したため, 壁面付近のバラストが流動しや寸くなって

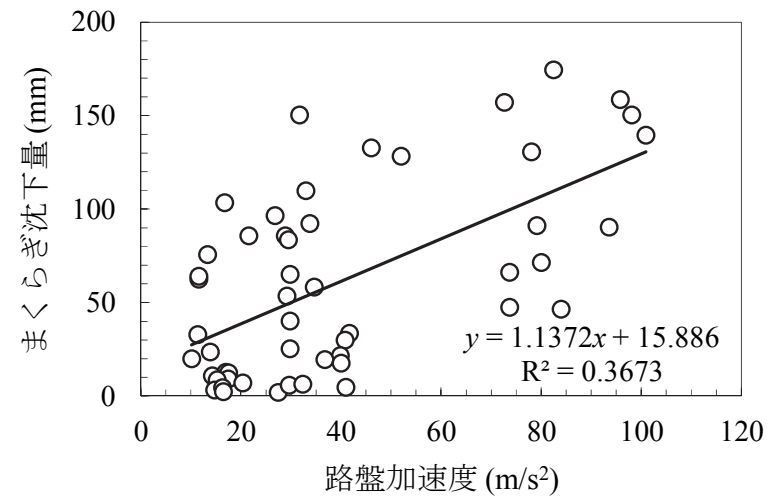

(a) 路盤加速度とまくらぎ沈下量の相関

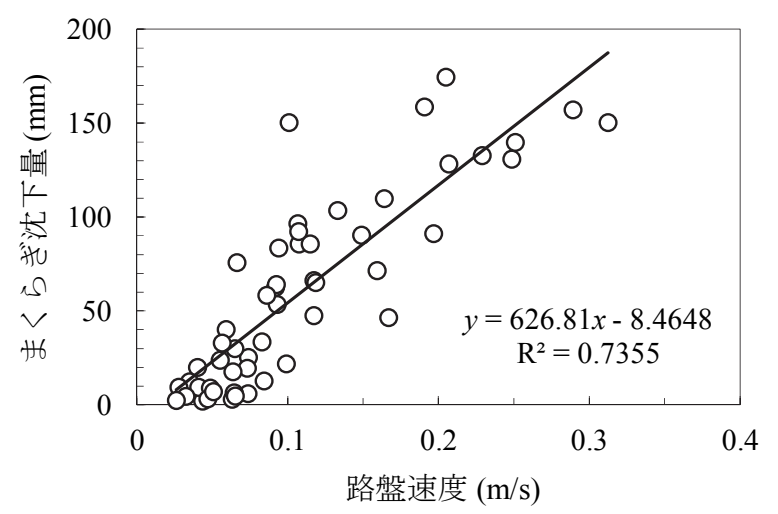

(b) 路盤速度とまくらぎ沈下量の相関

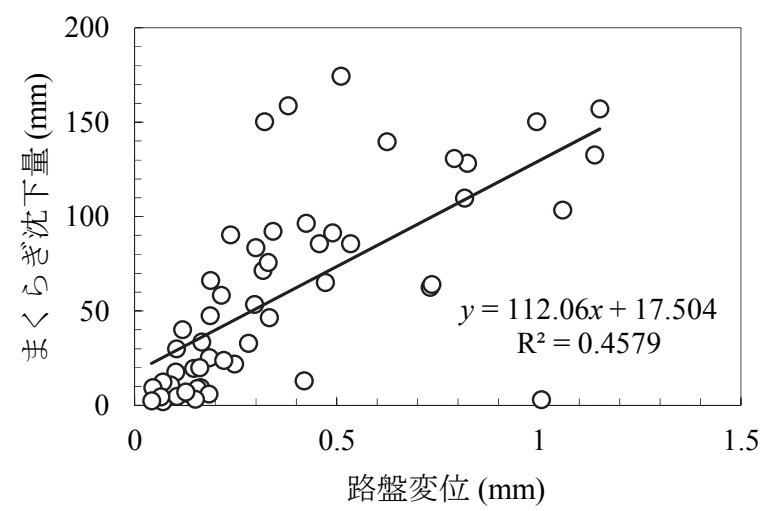

(c) 路盤変位とまくらぎ沈下量の相関

図-26 全解析ケースから得られたまくらぎ沈下量と 路盤応答の関係 


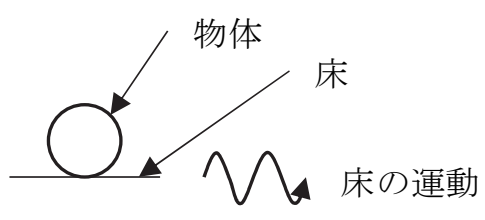

(a) 簡易モデル

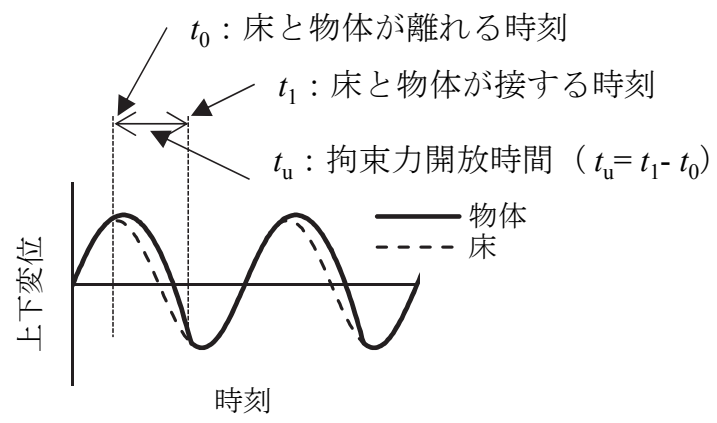

(b) 拘束力開放時間の概念

図-27 拘束力開放時間の考え方

いる．乙の影響で解析結果の沈下量が大きくなっている 可能性はあるものの，本解析で生じたまくらぎ沈下量の 増加は粒子間の摩擦が喪失することで発生するため, 壁 面の摩擦係数の影響は小さく，定性的な傾向を把握する うえで問題はないと考えられる.

次に，各路盤条件に対するまくらぎ沈下量がピークと なる周波数について考える. 荷重条件が P20- 140- $f-K$ シ リーズの場合，まくらぎ沈下量がピークとなる周波数は Roadbed-Aが 40Hz，Roadbed-B， Roadbed-Cが 64Hzであつ た. これは，解析モデルにおいてまくらぎ，バラストの 質量の合計と, 路盤ばね定数を 1 質点系の振動モデルと 考えたときの固有振動数（表-5）に概ね一致した。荷重

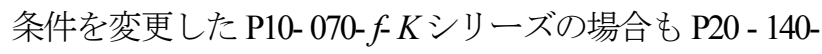
$f-K$ シリーズと全体的な傾向は同様であった。 また，図 24 を見ると, 路盤変位振幅の最大值も 1 質点系振動モデ ルの固有振動数に概ね正致していた。 バラスト粒子個々 の固有振動数は，100 Hz以上の領域に存在するため, 本 解析の載荷条件ではほとんど影響がなく，軌道全体の応 答は路盤条件の影響を大きく受けていることがわかる.

最後に，まくらぎ沈下量と路盤応答の関係について考 察する.まくらぎ沈下量と各路盤応答との相関を図-26 に示す．路盤速度振幅がまくらぎ沈下量に対して高い相 関を示しており，他の指標は相関が低い. 解析結果から, まくらぎ沈下量が載荷周波数など，動的な要素に依存性 があることは明らかなので，路盤変位振幅との相関が低 いのは妥当である. 路盤加速度については前述したよう にバラストの拘束圧と関係があるが，路盤加速度が重力 加速度以上になり，多くの接点で拘束力が 0 となって配
位数が減少すると加速度の影響が小さくなるために相関 が低くなったと考えられる。これに対して路盤速度振幅 は，載荷周波数や載荷荷重，路盤条件等をさまざまに変 化させた解析結果に対して一定の相関を示している．本 解析から, 路盤部に発生する振動の「速度振幅」がまく らぎ沈下量に対して最も相関の高いパラメーターである ことが分かった．次項でその理由について考察する。

\section{（4）路盤速度と拘束力開放時間の関係についての考察 a) 拘束力が開放される時間}

前節で路盤振動の加速度振幅が重力加速度以上になる と，バラスト粒子の平均配位数が減少し，バラストが非 常に不安定な状態になるためにまくらぎ沈下量が急増し た. 不安定状態にあるバラスト粒子に周囲のバラストと の接触などの外的作用が加わると，バラス卜粒子は容易 に微小移動を生じると考えられる。 こうした外的作用の 有無は，バラスト同士の位置関係などによりランダムに 生じるため, 確率的要因が強いと考えられる. しかし, バラスト粒子が不安定状態にある時間が長くなれば，そ れだけ外的作用が生じる可能性は高くなることになる.

そこで，本節では，図-27 に示すような単純化したモデ ルを用いて，バラスト粒子の拘束力が開放される時間と 路盤速度との関係を求める.

\section{b) 簡易モデルによる拘束力開放時間の計算}

図-27 に示すように，床上にひとつの物体が置かれた 状態で，この床が式(2)に示すように上下に運動すると きを考える。

$$
u_{f}(t)=r \sin \omega t
$$

ここで, $u_{f}$ : 床の変位, $r$ : 床の変位振幅, $\omega=$ $2 \pi f$ : 角速度, $f$ : 床の振動数である. このとき, 床の 振動加速度が重力加速度を超えなければ床と物体が離れ ることはない. 床の振動加速度振幅が重力加速度以上で 振動しているときは, 床の加速度がー $g$ （ $g$ は重力加速 度）より小さくなった瞬間に床と物体が離れて運動を始 める. 離れている間は物体は等加速度直線運動をしてい る. 今，床と物体が離れてから再び接触するまでの時間 を拘束力開放時間として，この時間を求める.

床が式(2)で運動しているとき，床の速度，加速度は それぞれ式(3)，式(4)で表される.

$$
\begin{gathered}
v_{f}(t)=r \omega \cos \omega t \\
a_{f}(t)=-r \omega^{2} \sin \omega t
\end{gathered}
$$

ここで， $v_{f}$ : 床の速度， $a_{f}$ : 床の加速度である. 今， $t=t_{0}$ のときに床から物体が離れ始めたとすると, 時刻 $t\left(t \geqq t_{0}\right)$ における物体の変位, 速度, 加速度は式(5) (7)のように表される. 


$$
\begin{gathered}
u_{m}(t)=u_{m 0}+v_{m 0}-\frac{1}{2} g\left(t-t_{0}\right)^{2} \\
v_{m}(t)=v_{m 0}-g\left(t-t_{0}\right) \\
a_{m}(t)=-g
\end{gathered}
$$

ここで, $u_{m}$ : 物体の変位, $v_{m}$ : 物体の速度, $a_{m}$ 物体 の加速度, $u_{m 0}: t=t_{0}$ の時の物体位置, $v_{m 0}: t=t_{0}$ の物体速度である. $t=t_{0}$ のとき, $u_{f}\left(t_{0}\right)=u_{m}\left(t_{0}\right)$, $v_{f}\left(t_{0}\right)=v_{m}\left(t_{0}\right), a_{f}\left(t_{0}\right)=a_{m}\left(t_{0}\right)$ となるので, それぞ れ式(2)から式(7)へ代入すると式(8)から式(10)となる.

$$
\begin{gathered}
u_{f}\left(t_{0}\right)=u_{m}\left(t_{0}\right)=r \sin \omega t_{0}=u_{m 0} \\
v_{f}\left(t_{0}\right)=v_{m}\left(t_{0}\right)=r \omega \cos \omega t_{0}=v_{m 0} \\
a_{f}\left(t_{0}\right)=a_{m}\left(t_{0}\right)=-r \omega^{2} \sin \omega t_{0}=-g
\end{gathered}
$$

式(10)を整理すると式(11)となる.

$$
t_{0}=\frac{1}{\omega} \sin ^{-1} \frac{g}{r \omega^{2}} \quad \text { ただし } g<r \omega^{2}
$$

$g<r \omega^{2}$ を満たすとき, $t=t_{0}$ で床から離れた物体が 再び床と接する時刻を $t_{1}$ とすると, $t=t_{1}$ のとき $u_{f}\left(t_{1}\right)=u_{m}\left(t_{1}\right)$ を満たす. よって式(2)から式(12)が求め られる。

$$
\begin{aligned}
u_{f}\left(t_{1}\right)=u_{m}\left(t_{1}\right)= & r \sin \omega t_{1} \\
= & u_{m 0}+v_{m 0}\left(t_{1}-t_{0}\right) \\
& -\frac{1}{2} g\left(t_{1}-t_{0}\right)^{2}
\end{aligned}
$$

式(12)に(8)，(9)を代入して式(13)が求められる.

$$
\begin{aligned}
r \sin \omega t_{1}= & r \sin \omega t_{0}+r \omega\left(t_{1}-t_{0}\right) \cos \omega t_{0} \\
& -\frac{1}{2} g\left(t_{1}-t_{0}\right)^{2}
\end{aligned}
$$

拘束力開放時間を $t_{u}$ とすると, $t_{u}=t_{1}-t_{0}$ より式(14) が求められる.

$$
\begin{aligned}
& \frac{1}{2} g t_{u}{ }^{2}-r \omega t_{u} \cos \omega t_{0}-r \sin \omega t_{0} \\
& =-r \sin \omega\left(t_{u}+t_{0}\right)
\end{aligned}
$$

式(14)より， $t_{u}$ は $r$ と $\omega=2 \pi f$ を与えることで求めら れる.

\section{c) 拘束力開放時間と路盤応答の相関}

式(14)から拘束力開放時間と床の運動との関係を求め たものを図-28 に示す。図では，床面の運動の周波数を $10 \mathrm{~Hz}, 20 \mathrm{~Hz}, 40 \mathrm{~Hz}, 60 \mathrm{~Hz}, 80 \mathrm{~Hz}, 100 \mathrm{~Hz}$ としたときの 拘束力開放時間を示している. 図-28(a), (c)を見ると, 床面の加速度, 変位に対しては, 床面の振動が $g<r \omega^{2}$ を満たしたところから拘束力開放時間は増加傾向となる ことがわかる.しかし，グラフから分かるように床の加 速度振幅および変位振幅からは拘束力開放時間が一意的

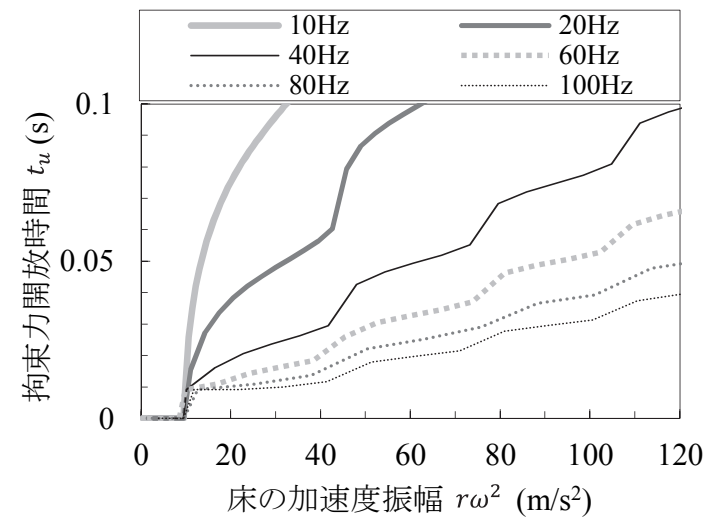

(a) 床の加速度振幅との関係

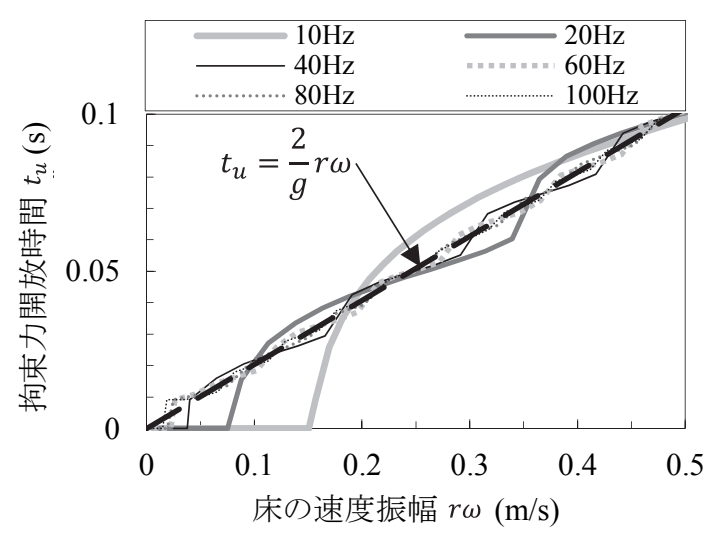

(b) 床の速度振幅との関係

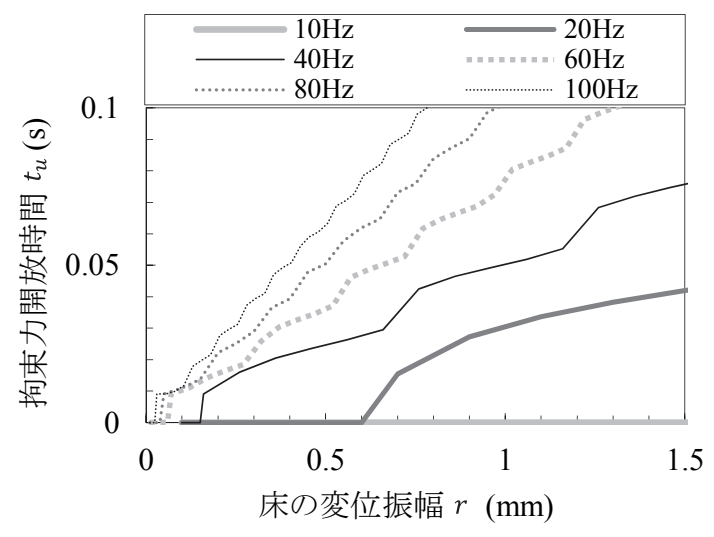

(c) 床の変位振幅との関係

図-28 式(14)の関係式から求めた拘束力開放時間

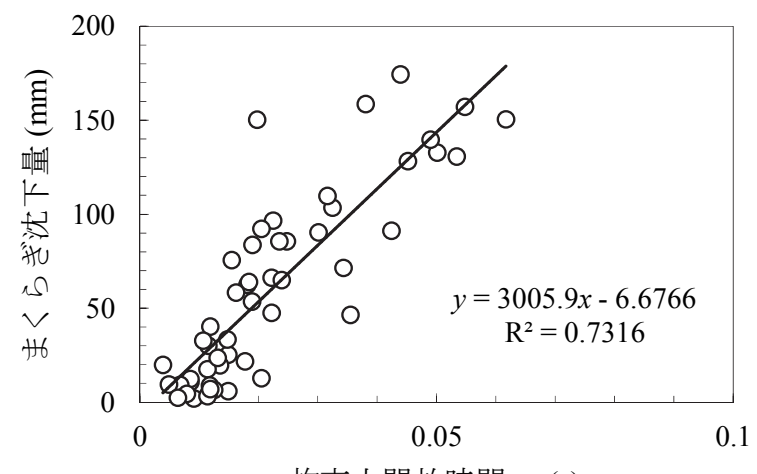

拘束力開放時間 $t_{u}(\mathrm{~s})$

図-29 拘束力開放時間と解析から得たまくらぎ沈下量の関係 
に決まらない，一方，図-28(b)の速度振幅は床面の振動 が $g<r \omega^{2}$ を満たすと，図中に黒の破線で示した以下の 式(15)に近い領域一遷移し，以降は式(15)に近い傾向を示 している.

$$
t_{u}=\frac{2}{g} r \omega
$$

式(15)は式(14)において, $\cos \omega t_{0}=1, \sin \omega t_{0}=$ $\sin \omega\left(t_{u}+t_{0}\right)=0$ として求めたものである. 式(14)は, 初速度 $r \omega$ で上向きに放たれた物体が床に落下寸るまで の時間を表している，これは，本モデルでは床から物体

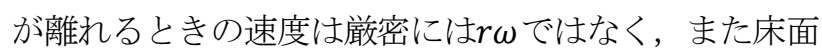
も上下に振動して位置が変動しているため, 一度浮き上 がった物体が床に落下寸るまでの時間に影響を与えるが, その影響は小さく, 床の速度振幅 $r \omega て ゙$ 概ね近似できる ことを示している. 図-28(b)の関係から，床面の速度振 幅は拘束力解放時間と比較的線形の関係が成立し, また 床面の振動周波数に関わらず一意的に速度振幅から拘束 力開放時間が求まることがわかる.

表-7の各ケースの解析から得られた路盤の変位振幅か ら式(14)を用いて算出した拘束力開放時間と解析から得 られたまくらぎ沈下量の関係を図-29 に示す。この図か ら分かるように，拘束力開放時間も路盤速度同様にまく らぎ沈下量と高い相関を示している。 つまり，本項のa) で述べた仮説のとおり, バラスト軌道の沈下は, 重力加 速度以上の路盤振動によってバラストが不安定状態とな る拘束力開放時間に概ね比例して増加している. そして 拘束力開放時間は路盤の速度振幅と線形に近い関係にあ るため，まくらぎ沈下量は路盤速度に線形の相関を示し ていると考えられる.

また，図-28(c)に示した路盤変位で見ると，10 Hzでは 変位振幅が $2.5 \mathrm{~mm}$ 以上にならなければ拘束力開放時間 が発生しない. 一方, $40 \mathrm{~Hz}$ では約 $0.15 \mathrm{~mm}$ 以上で発生す る. 2 章の試験結果（図-6）からも, 軟弱な路盤条件も 載荷周波数が $10 \mathrm{~Hz}$ では拘束力開放時間は発生しておら ず， $40 \mathrm{~Hz}$ では発生していると考えられ，載荷周波数が 高いほうが発生しやすいことがわかる.1 章でも述べた ように，高速鉄道では列車通過に伴って加振される周波 数が $30 \mathrm{~Hz}$ 以上になることから, 拘束力開放時間が発生 することによって生じる軌道沈下は, 在来線では発生し にくく, 高速鉄道において発生しや寸い現象であると考 えられる.

本解析では載荷条件，路盤条件，載荷周波数をさまざ まな值に設定しているが，すべての条件に対して路盤速 度とまくらぎ沈下量は一定の相関を持っている. 寸なわ ち, 本解析結果からは, 路盤速度を指標とすることで, 路盤岡性や載荷時の周波数などに依存せずに軌道沈下速 度を推定できる可能性があるといえる。

\section{5. 結言}

本研究では，まくらぎから入力される繰返し荷重や， それによって生じる路盤振動が軌道沈下を発生させるメ カニズムについて, 実物大軌道における繰返し載荷試験 および2次元個別要素法を用いた解析により解明した. 以下に得られた知見を述べる。

（1）軌道の沈下量は，同一の荷重条件では路盤剛性が小 さいほうが大きくなる.

（2）軌道の沈下挙動には，まくらぎからの荷重によって 生じる路盤振動が大きく影響する。 また, 路盤振動 加速度が重力加速度以上であることが急激なまくら ぎ沈下を発生させる条件となる。

（3）まくらぎ沈下量は載荷周波数の増加に対してある周 波数でピーク值を有し，ピーク以降は周波数の増加 に伴い軌道沈下量は減少する. また，このピークを 生じる周波数はまくらぎおよびバラストの質量の和 を質点, 路盤剛性をばねとしたときの1 質点系の固 有振動数と概ね一致する.

（4）まくらぎ沈下量はバラスト粒子の拘束力が低下寸る 時間と相関が高く, さらに路盤速度がその時間と線 形に近い関係となるため, まくらぎ沈下量が路盤速 度に対して高い相関を示寸。また, 路盤剛性や載荷 時の周波数などの条件が変化してもまくらぎ沈下量 と路盤速度は一定の関係を示寸。

\section{参考文献}

1) 村本勝己, 関根悦夫 : 繰返し荷重に対するバラスト 軌道の沈下特性, 土木学会第 55 回年次学術講演会, III-A213, 2000.

2) 古川敦, 泉栄治 : 実物大バラスト軌道模型載荷試験 による軌道沈下量算定式の導出, 第 15 回鉄道技術 政策連合シンポジウム(J-RAIL2008), 講演論文集, pp. 403-406, 2008.

3) 佐藤吉彦: 東海道新幹線において 951 形式電車に発生 した著大輪重とその対策, 鉄道技術研究報告, No. 824, 1972.

4) 三浦重 : 軌道構造の動特性モデルの構築, 鉄道総研 報告, Vol. 9, No. 12, 1995.

5) 川崎祐征, 三輪昌弘, 吉村彰芳 : 車両/軌道の相互 作用の数值解析方法に関寸る一考察, 第 16 回鉄道技 術連合シンポジウム講演論文集, pp. 693-696, 2009.

6) 佐藤裕：繰返荷重による道床沈下の実験，鉄道技術 研究報告, No. 65, 1959.

7) 名村明, 石川達也, 三浦重, 内田雅夫, 堀池高広: 有道床軌道の道床沈下の定量化に関寸る基礎的検討, 鉄道総研報告, Vol. 7, No. 10, 1993.

8) 千田耕大, 三輪昌弘, 川崎祐征: 軌道狂い進みに伴 うバラスト挙動の経時変化に関する一考察, 第 71 回 年次年次学術講演会講演概要集, DVD-ROM, 2016.

9) 千田耕大, 三輪昌弘, 川崎祐征, 松島亘志: 路盤剛 性と加振周波数がバラスト軌道の沈下特性に与える 影響, 第 21 回鉄道工学シンポジウム論文集, pp. 121- 
$128,2017$.

10) 新版軌道材料編集員会 : 新版 軌道材料, pp. 248, 鉄 道現業社，2011.

11) 新版軌道材料編集員会 : 新版 軌道材料, pp. 363 , 鉄 道現業社，2011.

12) 財団法人鉄道総合技術研究所編：鉄道構造物等設計 標準・同解説一土構造物，pp. 92，丸善， 2007.

13）関根悦夫，河野昭子，村本勝己，石川達也：列車荷 重を受けるバラスト軌道の塑性変形に及ぼす路盤剛 性の影響, 第 40 回地盤工学研究発表会, 2005

14) 株式会社東京測器研究所 : FWD-Light 小型 FWD シス テム, http://www.tml.jp/product/special_ins/fwd-light/ index.html（閲覧日：2016 年 12 月 1 日）

15) Miwa, M. and Nakamura, S. : High speed running test and the new testing equipment for wheel/rail dynamic interaction, Proc. of Int. Symposium on Speed-up and Service Technology for Railway and Maglev Systems (STECH'03), JSME, pp. 489-493, 2003.

16) 新版軌道材料編集員会: 新版 軌道材料, pp. 250-251,
鉄道現業社，2011.

17) 河野昭子，松島亘志：繰返し衝撃荷重下の砕石層の 動的挙動と沈下特性に関する実験的検討, 土木学会 論文集 A1（構造・地震工学）, Vol. 68, No. 1, pp. 173190, 2012.

18）日本国有鉄道：鉄道構造物等設計標準 (土構造物), 1978.

19) Matsushima, T. and Saomoto, H. : Discrete element modeling for irregularly-shaped sand grains, Proc. NUMGE: Numerical Methods in Geotechnical Engineering, Mestat (ed.), pp. 239-246, 2002.

20) 河野昭子, 松島亘志 : 繰返し衝撃荷重下の道床バラ ス卜層の動的挙動と沈下特性, 鉄道総研報告, Vol. 24, No. 12, 2010.

21）関根悦夫，石川達也，河野昭子：道床バラストの繰 返し塑性変形に及ぼす道床厚の影響, 鉄道総研報告, Vol. 19, No. 2, pp. 17-22, 2005.

(2017. 10. 5 受付)

\section{INFLUENCE OF ROADBED VIBRATION ON PLASTIC SETTLEMENT OF BALLAST LAYER}

\section{Kodai SENDA, Takashi MATSUSHIMA, Masahiro MIWA and Yoshiyuki KAWASAKI}

On ballasted track, to prevent track irregularities from growing is important in order to keep good riding comfort. The roadbed vibration caused by train have a great influence on the growth of track irregularities. In this study, we considered the influence of roadbed vibration on track settlement by experiments using full-scale ballasted track model and simulation using the Discrete Element Method. As a result of the study, it is quantitatively showed that the track settlement increases as the roadbed vibration increases. Further, it is clarified that the track settlement rapidly increases if the roadbed acceleration exceeds the gravitational acceleration, and that the track settlement correlates with the velocity amplitude of the roadbed. 